\title{
The Structure and Affinities of Macroglossum Alidae, Copeland.
}

\author{
BY \\ DOUGLAS HOUGHTON CAMPBELL, \\ Leland Stanford Fr. University, California.
}

\section{With Plates XLVI-XLVIII and eight Figures in the Text.}

$\mathrm{T}$ $\mathrm{HE}$ discovery of a new generic type in such a group as the Marattiales is an event of more than ordinary interest. Such a type is the recently established genus $M$ acroglossum, ${ }^{1}$ based upon a remarkable Fern sent from Sarawak, in Borneo.

A recent visit to the East Indies enabled the writer to visit Sarawak, and to collect material of this Fern at the original station, near Bau. Through the kindness of Mr. J. C. Moulton, Director of the Sarawak Museum, and Mr. Young, the head of the Gold Mining Works at Bau, the writer secured a supply of material, including a number of prothalli and young sporophytes as well as specimens of the adult plant.

The plants were found to be pretty abundant at the place where they were first collected, and ranged in size from the original specimen, a magnificent plant with fronds nearly four metres in length, to very young specimens just emerging from the prothallus.

Soon after the plant was first collected at Bau, Mr. Moulton found it near Mount Penrissen, also in Sarawak. The writer collected a single specimen of Macroglossum at the foot of Mount Mattang, about ten miles from Kuching, but the sporangia were very young, and it is possible that it was not the same species and may have been the same as a plant grown in the Botanical Gardens at Buitenzorg in Java under the name Angiopteris Smithii. This plant was only about half the size of the Bau specimens, and, to judge from the immature sori, they were more like $M$. Smithii and so perhaps identical with it.

After leaving Sarawak the writer visited Java, and in the Botanical Gardens at Buitenzorg a single fruiting specimen of Macroglossum was found. The plant had been in the gardens for many years, but its origin is unknown. Presumably it had been sent with other plants from Borneo by collectors, but there was no record of it, so it is impossible to say

1 Copeland, E. B. : Ferns of the Asiatic-Malay Region. Philippine Journal of Science, Botany, vol. iv, 1909.

[Annals of Botany, Vol. XXVIII. No. CXII. October, 1914.] 
whether it came from Sarawak or from Dutch Borneo. The plant was somewhat smaller than the specimens of $M$. Alidae from Bau, but it was assumed to be the same species. A further examination, however, has shown a number of differences, especially in the sporangium, and it should probably be considered specifically distinct. The plant at Buitenzorg is the type of Raciborski's Angiopteris Smithii, ${ }^{1}$ but there is no question that it should be transferred to the genus Macroglossum, and would therefore become Macroglossum Smithii.

The full-grown plant is very striking in appearance. From the short caudex arise the closely set, simply pinnate, massive leaves, which attain a length of nearly four metres. They stand almost vertical, and the appearance of the plant is very different from that of any species of Angiopteris, whose bipinnate leaves are much less closely set, and usually spread out widely from the caudex. The leaves are arranged spirally about the stem, which is apparently always radial in structure. The leafbase is much enlarged and the stipules very conspicuous. The latter are united in front by a broad commissure (Pl. XLVIII, Fig. C). The leaves are simply pinnate, the pinnae, which are closely set, being sometimes more than $50 \mathrm{~cm}$. in length. They are very thick, with quite smooth margins in the adult plant.

In general habit the plant more nearly resembles a large Danaea than it does Angiopteris. It also is superficially in habit like some of the large species of Zamia. This was remarked when the plant in the Buitenzorg gardens was compared with a Zamia growing not far away from it.

Plate XLVIII, Fig. B shows the caudex of a small individual with the leaf bases and the thick, much-branched roots.

The plants grew on a wooded bank above a small stream, and by examining the earth below the larger plants a number of prothalli were secured. As is usual with the Marattiaceae, the prothalli were most abundant where the earth had fallen away leaving freshly exposed surfaces. They are easily distinguished from the prothalli of ordinary Ferns by the more massive structure and the emergence of the primary leaf upon the upper surface of the gametophyte. Gametophytes of different ages were secured, some of unusually large size; and a number of young sporophytes of different ages were also collected.

\section{The Gametophyte.}

As in all the Marattiales, the gametophyte of Macroglossum is a darkgreen thallus with a very thick midrib which projects strongly on the lower surface (Pl. XLVI, Fig. 4). The wings of the thallus, also, are comparatively thick and never composed of more than a single layer of cells, as

${ }^{1}$ Raciborski, M.: Über einige unbekannte Farne des Malayischen Archipels. Bull. Acad.d. Sciences, Cracovie, 1902. 
in the leptosporangiate Ferns. The larger prothalli (e.g. Pl. XLVI, Fig. 5) are so much like a thallose Liverwort in appearance that it is necessary to make a close examination before their real nature is apparent. The presence of the old archegonia upon the ventral surface, however, can usually be easily demonstrated.

The younger prothalli show the familiar heart-shaped form, with a deep sinus, which becomes much less evident in the older stages and may become quite obsolete.

There was no opportunity for studying the germination of the spores and the early stages of the gametophyte, but it is highly probable that they would agree closely with those of Marattia and Angiopteris, described in detail by Jonkman. ${ }^{1}$

Pl. XLVI, Fig. 1 shows the youngest stage collected by the writer. This was $5 \mathrm{~mm}$. in length, with a deep sinus in front. The posterior part was much narrower and the thickened midrib was confined to the anterior broader portion. The bottom of the sinus was occupied by a row of marginal initials of the usual type, and the first antheridia and archegonia had already been formed. The antheridia are developed first and are borne both upon the upper and lower surfaces of the thallus. On the upper side they form a median group a short distance behind the growing point of the prothallus, while on the lower surface they form two small groups on either side of the midrib. The group of young archegonia occupies the centre of the midrib between the two ventral groups of antheridia and the apex of the thallus (Fig. 2).

The older prothalli (Pl. XLVI, Figs. 3-5) show a less conspicuous sinus and may be almost orbicular in outline. In these older gametophytes the midrib is extremely conspicuous and its surface covered with great numbers of old archegonia which are visible to the naked eye as darkbrown dots. Numerous rhizoids are present in the basal region, but they are much less developed in the younger parts of the gametophyte.

The gametophytes are evidently long-lived and may reach a very considerable size. The specimen shown in Fig. 5 was nearly three centimetres in length. The apex had been injured and from the broken surface adventitious buds were forming. This multiplication of the prothallus by budding is not at all a rare phenomenon among the Marattiaceae. ${ }^{2}$ A true dichotomy of the thallus apex probably also occurs, as it does in some other Marattiaceae. The gametophyte shown in Pl. XLVI, Fig. 7, with two nearly equal branches, probably was the result of the dichotomy of the original thallus apex. 1880.

1 Jonkman, H. F.: La Génération sexuée des Marattiacées. Arch. Néerlandaises, etc., t. xv,

2 Campbell, D. H.: The Eusporangiatae. Carnegie Institution of Washington, Publication No. I40, I9II. 
The apex of the gametophyte is occupied by a row of similar marginal cells, no one of which can be certainly identified as a single apical cell (P1. XLVI, Fig. I2), although it is possible that the central cell of the marginal row may be a definite apical cell. In horizontal section the marginal cells are oblong, and narrower in front. A vertical section shows the usual form found in Fern prothalli, i.e. it appears semicircular with single basal segments extending the whole depth of the thallus (Pl. XLVI, Fig. I3).

\section{The ANTHERIDIUm.}

The antheridium in Macroglossum is very much like that of the other Marattiaceae in its development. Antheridia are produced abundantly both on the dorsal and ventral surfaces of the prothallus. As in all of the eusporangiate Ferns, the mother-cell first divides into an inner and an outer cell, the former by subsequent divisions giving rise to the mass of spermatocytes; the outer one, by a series of intersecting walls, forming the cover. There is a more or less regular quadrant division of the inner cell (Pl. XLVI, Fig. I5), beyond which it is not possible to trace any regular sequence in the divisions of the sperm-cells.

Surrounding the mass of sperm-cells there are later cut off from the adjacent tissue the characteristic narrow, mantle cells (Figs. I 8, I9, m.).

In the cover cells, as in other Marattiaceae ${ }^{1}$ and in Ophioglossum, a series of intersecting walls is formed, the last division cutting out a small triangular opercular cell, which is destroyed at the time of dehiscence (Figs. 20, 2I).

The number of spermatocytes is very large in Macroglossum, probably exceeding that of any other of the Marattiaceae. In the larger antheridia as many as a hundred spermatocytes may be seen in a single section. The spermatozoids, however, are smaller than is usual in the Marattiaceae.

The development of the spermatozoid is entirely like those of other Marattiaceae. The nucleus of the spermatocyte has no nucleolus and soon begins to assume the characteristic curved form (Pl. XLVI, Fig. 22), finally becoming much elongated. The blepharoplast, which at first is globular, very soon becomes elongated and forms a slender coiled body lying along the curve of the nucleus. From the blepharoplast the cilia are developed, but the details were not followed, as there seemed to be no peculiar features present. The free spermatozoids were not seen.

On comparing the spermatozoids with those of Angiopteris (P1. XLVI, Fig. 24) they are found to be slightly smaller and the nucleus rather less elongated. In the latter respect Macroglossum perhaps more nearly resembles Danaea than it does Angiopteris. 


\section{The ArChEgonium.}

The archegonium of Macroglossum does not differ essentially from that of the other Marattiaceae, perhaps being most like that of Angiopteris. The mother-cell is divided into two by a transverse wall, the outer cell giving rise to the short neck, the inner one either first dividing into a basal cell and a central cell, or giving rise directly to the egg-cell and canal cells, the basal cell being suppressed (Pl. XLVII, Figs. 25, 26). The cover-cell, as usual, divides first by intersecting walls into four primary neck-cells, each of which undergoes division once or twice, so that each of the four series of neck-cells contains two or three cells (Figs. 29-3I). It is possible that occasionally a third division occurs, but this is not usually the case.

The central cell, as in other Ferns, pushes up between the neck-cells, and this narrow upper part is separated from the lower broad portion as the primary neck canal cell, which subsequently divides into two either by the formation of a cross-wall or simply by a division of the nucleus. From the central cell a conspicuous ventral canal cell is cut off, as in Marattia and Angiopteris (P1. XLVII, Figs. 30-32).

Where a basal cell is present it undergoes several divisions, but there seems to be no definite sequence of cell-divisions, and the basal cell is not always recognizable. Compared with Angiopteris (Fig. 33) the neck canal cells seem to be rather narrower in Macroglossum, otherwise the archegonia are very similar.

\section{THE EMBRyo.}

Only a few of the young embryos were found, but these showed a very notable difference when compared with the embryo of Angiopteris. In Macroglossum there is a very large suspensor developed, and in this respect it resembles Danaea, ${ }^{1}$ but the suspensor is much larger.

Several one-celled embryos were seen. These filled up the venter of the archegonium and varied somewhat in shape (Pl. XLVII, Figs. 34, 35). In one case a two-celled embryo was seen (Fig. 36) which closely resembled a corresponding stage in Danaea. The upper part was somewhat pointed and formed the beginning of the suspensor. Another stage is shown in Fig. 39 .

The suspensor was extraordinarily developed in the older embryos that were found, but differed in position from the suspensor of Danaea. In the latter, the suspensor, which is quite short, pushes the embryo downward, so that the long axes of the suspensor and embryo coincide. To judge from the few specimens secured in Macroglossum this is not the case. The suspensor grows laterally, pushing the embryo a long distance sideways from the archegonium (Pl. XLVII, Fig. 37). How far this large 
suspensor is derived from the original suspensor cell, and how much, if any, is derived from the hypobasal cell, must for the present remain doubtful.

The embryo, except for the suspensor, is much like that of Angiopteris at the same stage. It is much flattened, and near the centre of the upper surface could be seen a cell which may possibly represent the stem-initial (Fig. 38). The root-initial had not yet been differentiated, but it probably arises from the central region of the embryo, as it does in the other Marattiaceae.

Pl. XLVII, Figs. 40-42 show three transverse sections of an embryo in which the root is just differentiated. Fig. 42 passes through the foot, and shows part of the thick lateral suspensor (sus.). Fig. 4I is a nearly median section, and passes through the root-initial $(r$.), from which the first segment has been cut off. As in the other Marattiaceae, the root is a strictly endogenous structure, the initial cell arising near the centre of the embryo, probably from the lower part of the epibasal region. Fig. 40 shows the upper surface of the embryo. The large cell (st.) perhaps is the apical cell of the stem, but this is not certain.

No large embryos were found, the youngest sporophytes obtained having the cotyledon well developed and the root penetrating the ground. Sections of such sporophytes (PI. XLVII, Fig. 43) show the same arrangement of the organs as in other Marattiaceae. ${ }^{1}$ As is usual in these Ferns, the young sporophyte has the axis of the cotyledon coincident with that of the root, a common vascular bundle extending without interruption from the leaf into the root. The stem-apex is inconspicuous and consists of a shallow group of large cells, so much alike, that it is not easy to distinguish the actual apical cell. In Pl. XLVII, Fig. 44, it is probable that the large cell (st.) is the initial cell of the stem-apex, but this is not certain. In the few cases found, the initial cell in longitudinal section appeared oblong in form.

The second leaf makes its appearance very early, and there is soon discernible a strand of procambium cells, representing the second leaf-trace, connecting the leaf rudiment with the common bundle of the primary leaf and root. As in the other Marattiaceae there is no evidence at this stage of any true cauline bundle or stele. ${ }^{2}$ The cotyledon, like that of Angiopteris, shows a good deal of variation. It is usually fan-shaped, with a more or less marked dichotomous venation, but there is frequently a more or less distinct midrib, and sometimes the cotyledon is almost lanceolate in outline, with a conspicuous midrib (Pl. XLVI, Fig. 6) and lateral veins.

Text-fig. I shows a series of cross-sections from a young sporophyte in which the second leaf was just discernible. The stem-apex is occupied by a group of meristematic cells, among which it is not easy to recognize with certainty a single initial cell.

\footnotetext{
1 See Campbell, loc. cit.
} ${ }^{2}$ See Campbell, loc. cit. 
A section taken a short distance below the apex (B) shows the leaftrace belonging to the cotyledon, in which the first tracheary tissue can be seen, and near it a second group of cells forming the trace for the second leaf.

The primary leaf-trace shows a small group of reticulate tracheides near its inner side and may be described as collateral, in this respect resembling Danaea. Sections taken still lower down show the coalescence of the two leaf-traces into a single strand, which is continued directly into the primary root. This axial bundle, after the fusion of the leaf-traces is complete, has the tracheary tissue forming a short band in cross-section occupying the middle of the bundle ( $\mathrm{E})$. The stele of the primary root is, usually at least, diarch, and probably derives its two xylems from the first and second leaf-traces respectively.

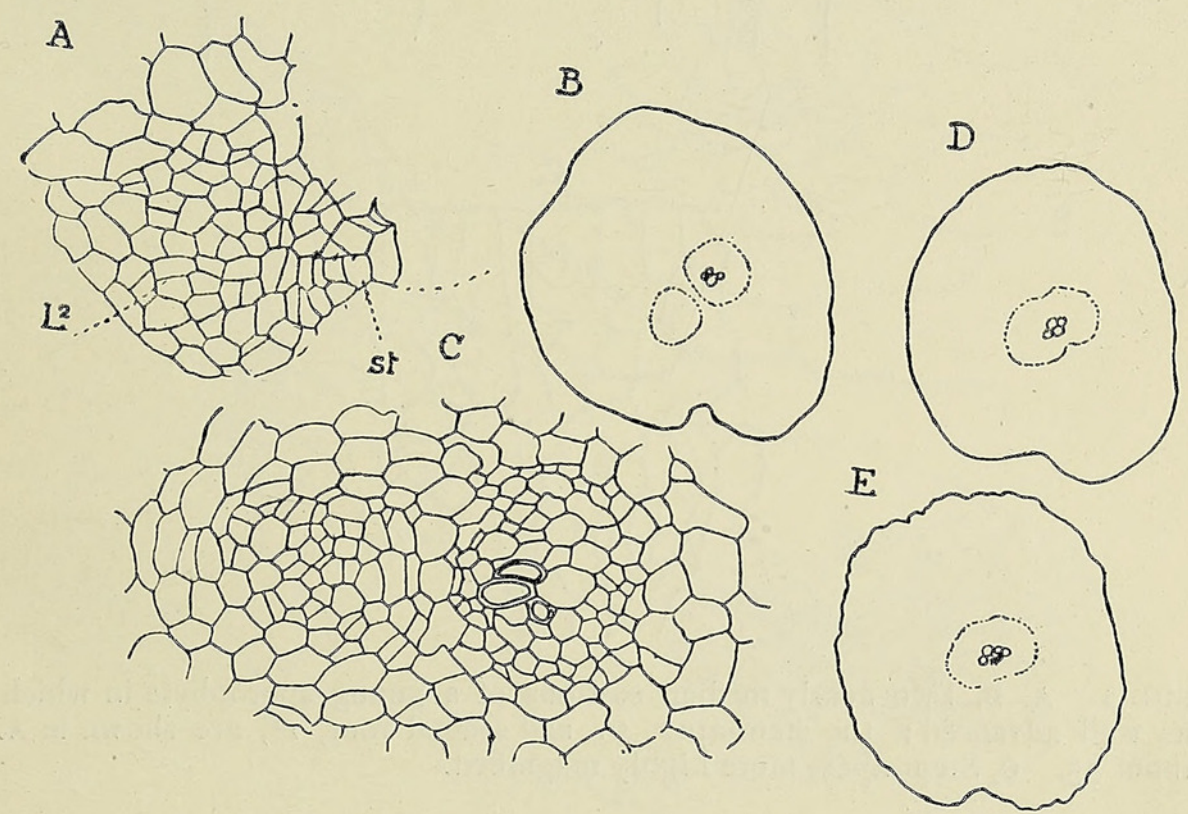

TEXT-FIG. I. $\Lambda$, Transverse section passing through the apical region of a young sporophyte, in which the second leaf $\left(L^{2}\right)$ was just recognizable. st., stem. $\times 180 . \quad$ B, Section taken a short distance below the apex, showing the separate traces of the first and second leaves. $\times 50 . \quad \mathrm{C}$, Central region of B. $\times$ I80. D, E, Sections taken further down, showing the union of the leaf-traces. $\times 5^{\circ}$.

Text-fig. 2 shows two longitudinal sections of a sporophyte in which the second leaf was already pretty well advanced, and the third could also be seen. In A the second leaf is cut almost in the median plane, and the single vascular bundle is clearly seen. In $\mathrm{B}$ the section traverses the cotyledon, and shows the continuity of the vascular bundles of the cotyledon primary root. The junction of the second leaf-trace with the primary vascular strand is also shown. At this stage the second root is evident, arising close to the base of the second leaf-trace, with which its vascular cylinder is united. C shows the stem-apex of this sporophyte. The large oblong cell in which the nucleus is shown is probably the single initial, but the segmentation appears to be very irregular. Below the apex there 
is a mass of irregular isodiametric cells, and no evidence of a procambium cylinder, the elongated cells lower down being assignable to the leaf-traces.
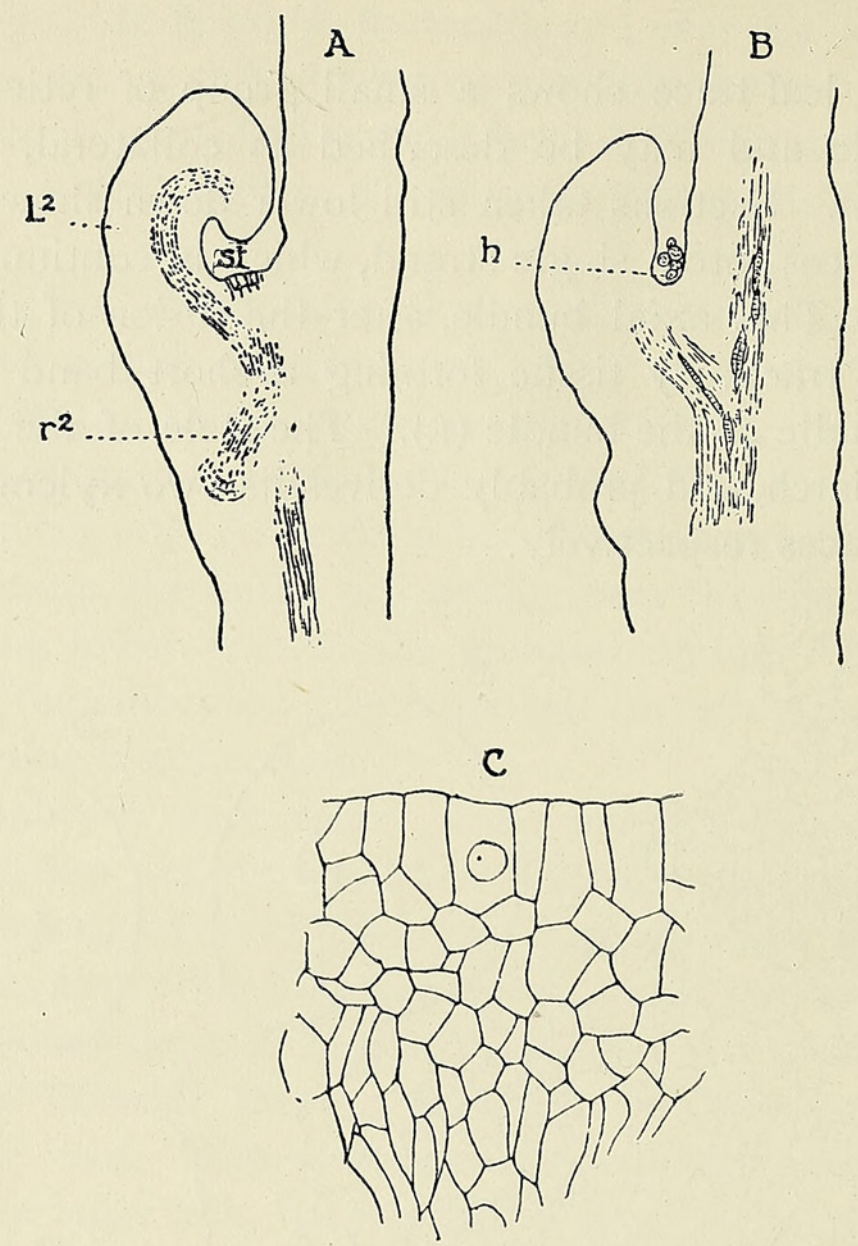

TEXT-FIG. 2. A, B, Two nearly median sections of a young sporophyte in which the second leaf, $L^{2}$, was well advanced; the stem-apex, st., and second root, $r^{2}$, are shown in $A_{.} h$, tannin hairs. $\times$ about 35 . c, Stem-apex, more highly magnified.

\section{The Cotyledon.}

As has already been indicated, the form of the cotyledon is somewhat variable. The petiole is more or less strongly winged, but no stipules are developed. Text-fig. 3, A, shows a section of the petiole. The conspicuous vascular bundle is elongated in cross-section and is concentric in structure, the phloem being of nearly equal width all round, although somewhat less developed on the ventral side. No definite endodermis can be recognized. No mucilage ducts are present, but there are a number of tannin cells, filled with opaque dark contents. These form an irregular ring about the vascular bundle.

The epidermis is much alike on the two sides of the leaf, except that stomata are developed only upon the lower surface. The mesophyll does not show any development of palisade cells, but is composed of about half a dozen layers of nearly uniform cells with irregular intercellular spaces, 
which are somewhat more conspicuous upon the lower side of the leaf. The bundles of the delicate veins approach the collateral form, the small group of tracheary tissue being nearer the ventral side of the bundle and separated from it by about two layers of cells.

New leaves are formed in rapid succession. The second or third are much like the cotyledon, except that they are slightly larger. These early leaves have finely but distinctly serrated margins. The next leaves are lanceolate in outline, and in the later leaves the margins are almost entire except at the apex, which becomes much attenuated and is coarsely serrate. A considerable number, ten or more, of simple leaves are developed before
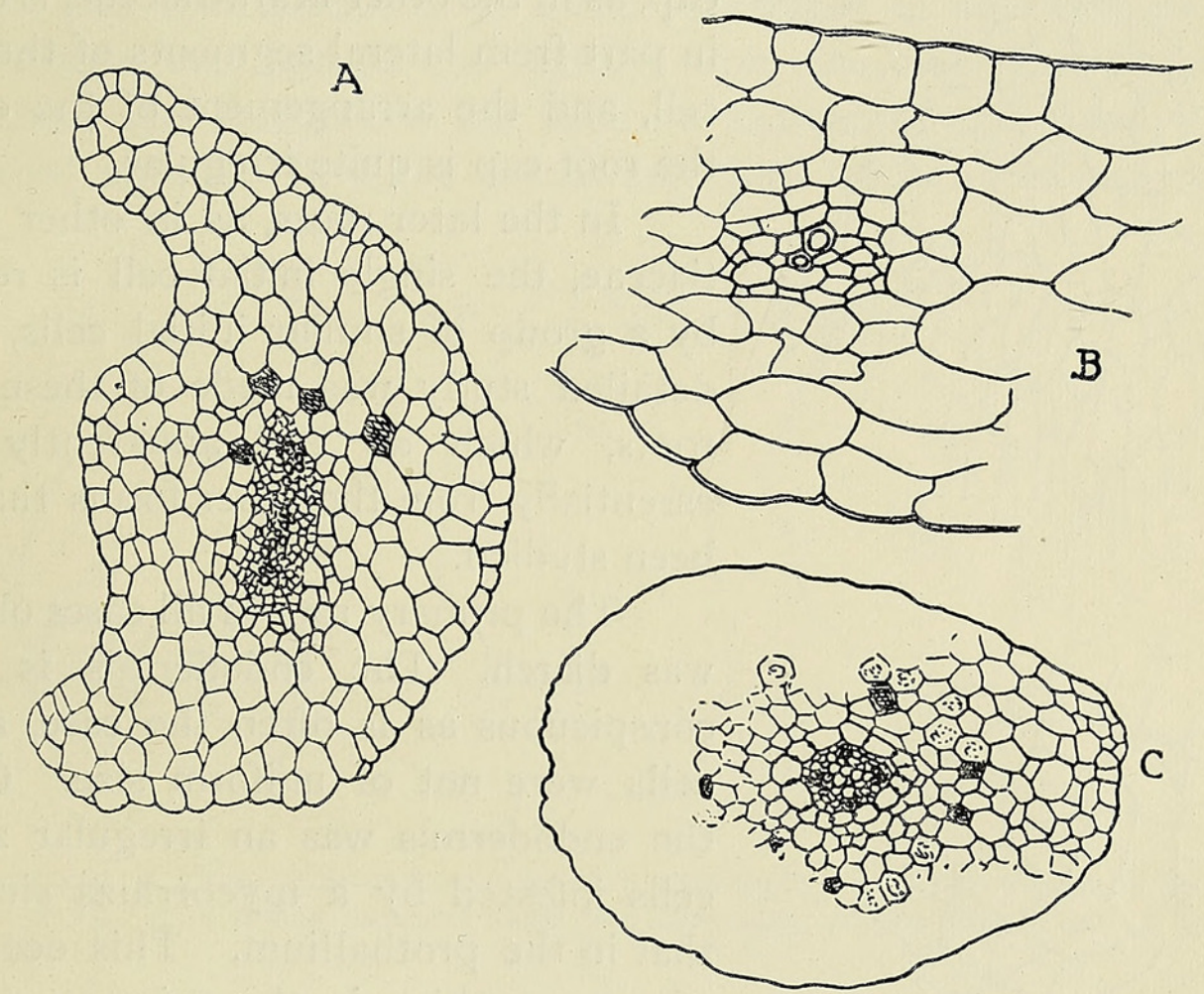

TEXT-Fig. 3. A, Section of petiole of cotyledon. $\quad \times 25 . \quad$ B, Section of lamina of cotyledon. $\times$ I80. C, Section of tetrarch root. $\times 50$.

any division of the lamina occurs. These simple leaves are much larger than has been observed in Angiopteris, and a greater number are formed. In this respect Macroglossum more nearly resembles Danaea, but these early leaves are much larger. Indeed, such a plant as that shown in Pl. XLVIII, Fig. A, much resembles the adult plant of $D$. simplicifolia. All of the early leaves have a conspicuous midrib from which the lateral veins extend. These veins usually fork close to the midrib, and the branches may extend to the margin, or they may fork once more. As in Angiopteris and Marattia, the first two leaves are destitute of stipules, which are first developed in the third leaf (P1. XLVI, Figs. 8, 9). For a time, at least, a root is formed corresponding to each leaf, but whether this holds for the old sporophyte was not investigated. 


\section{THE PRIMARY RoOT.}

The primary root in Macroglossum, as in the other Marattiaceae, has a single initial cell. This appears in longitudinal section nearly triangular in outline, but is sometimes more or less truncate below (Text-fig. 4, A). The cross-section also is irregularly triangular in outline (Text-fig. 4, $\mathrm{B}$ ). There was not available sufficient material to make a complete study of the apical growth of the primary root, and it is probable that an examination of a considerable number would show some variation in the form and

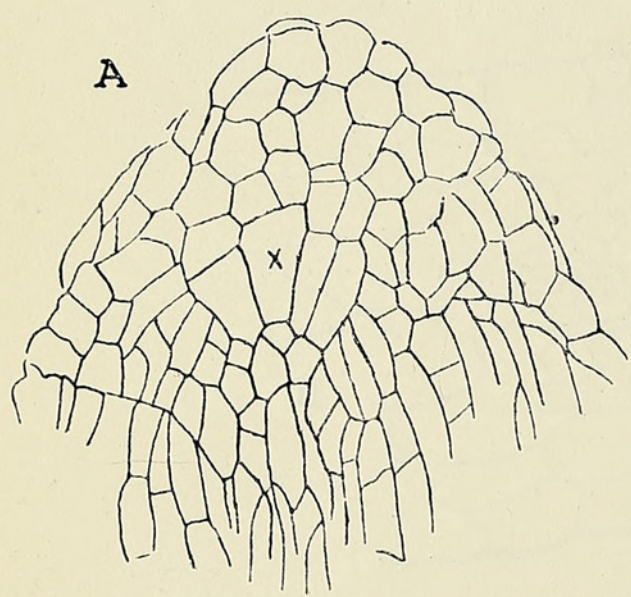

$B$

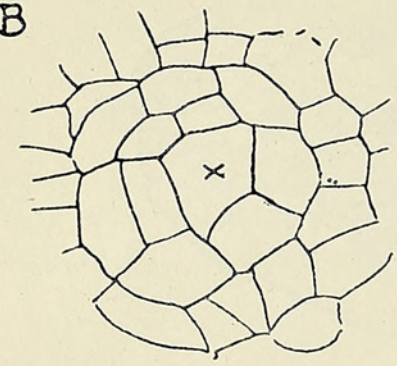

Text-FIG. 4. A, Longitudinal section of apex of first root, showing the single initial cell $(x) . \quad \times 250 . \quad$ B, Transverse section of root-apex. $\quad x$ about $25^{\circ}$. segmentation of the apical cell. The rootcap, as in the other Marattiaceae, is derived in part from lateral segments of the apical cell, and the arrangement of the cells of the root-cap is quite irregular.

In the later roots, as in other Marattiaceae, the single initial cell is replaced by a group of similar initial cells, but no detailed study was made of these larger roots, which do not apparently differ essentially from the other forms that have been studied.

The primary root in all cases observed was diarch. The endodermis is not as conspicuous as is often the case, and its cells were not of uniform size. Outside the endodermis was an irregular zone of cells infested by a mycorrhiza similar to that in the prothallium. This occurrence of a mycorrhiza in the primary root has been noted in other Marattiaceae. ${ }^{1}$

The second root may show a triarch bundle (Text-fig. 5, D), and as the roots become larger the number of xylems increases.

The first and second leaves of the young sporophytes are destitute of stipules, which first make their appearance in the third leaf (Pl. XLVI, Fig. 9). These first stipules are small, with somewhat serrate margins. The stipules become large in the later leaves, and soon are very conspicuous (P1. XLVI, Fig. II). These large stipules are joined in front by a commissure, and completely enclose the next younger leaf.

The nature of the vascular system in the stem of the Marattiaceae has been examined critically by the writer, ${ }^{2}$ and the conclusion was reached that no true cauline stele was present in the young sporophyte, whose 
vascular system was composed entirely of leaf-traces. Several of the young sporophytes of Macroglossum were cut transversely for comparison with the other Marattiaceae, and, as in these, it was clear that the vascular system of the stem is at first composed of the leaf-traces alone. Text-fig. 5 shows several sections taken from such series. These sections resemble more nearly corresponding ones of Danaea than of Angiopteris, the leaf-traces remaining separate for a longer time than in Angiopteris. In the sporophyte figured below the fourth leaf-trace was just visible. A is taken a short distance below the stem-apex, and shows the four leaftraces completely separated. Close to the fourth leaf-trace is the beginning of the fourth root $\left(r^{4}\right)$. The leaf-traces in all cases show a concentric structure, and as the sections from the older part of the plant are examined, the leaf-traces are seen to converge, and finally unite into a central strand. In $\mathrm{C}$ the second and third traces are completely united,
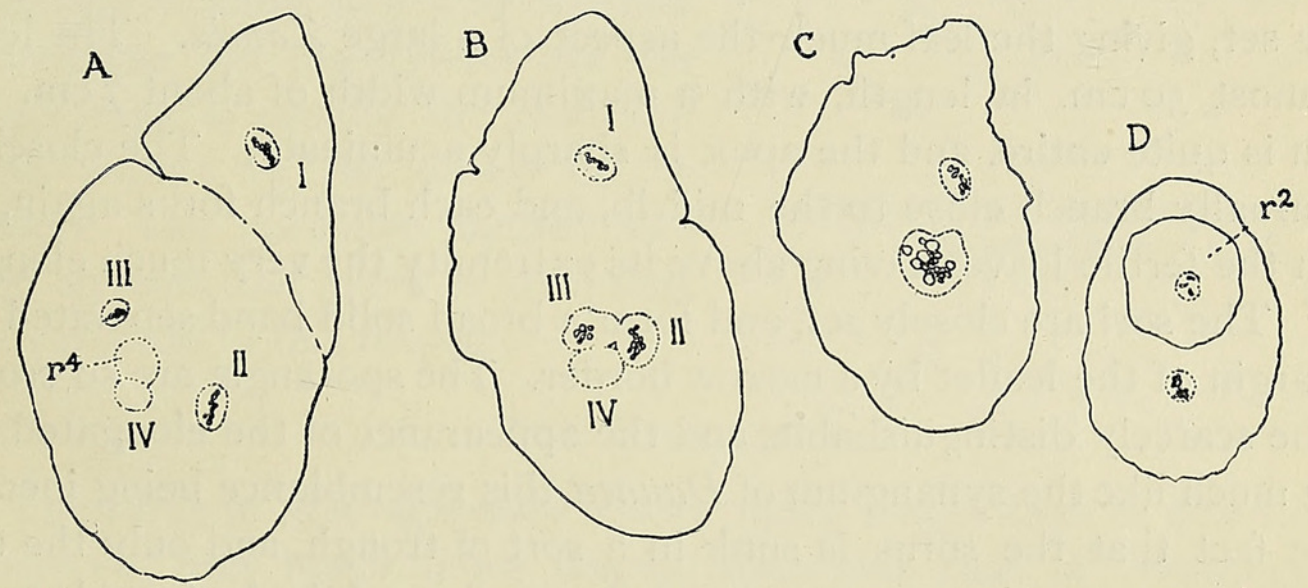

TEXT-FIG. 5. Four sections from a series of a sporophyte in which the fourth leaf was still very young. $\quad \times 25$. The roman numbers show the leaf-traces; $r^{4}$, the fourth root; $r^{2}$, section of the second root.

but the primary leaf-trace is still free. In $\mathrm{D}$ is shown a section in the transition region between the cotyledon and primary root. The triarch second root $\left(r^{2}\right)$ is shown also in this section.

Sections from the middle and basal regions of an older sporophyte confirm the impression that the central vascular strand or 'stele' is the result simply of the fusion of independent leaf-traces, and there is no evidence of its being continued as an independent strand into the stemapex. It is likely, however, as happens in the other genera, that later truly cauline bundles make their appearance, but this point was not investigated.

While Macroglossum resembles Danaea in the arrangement of the vascular bundles in the very young sporophyte, in other respects it is more like Angiopteris. In Danaea and Kaulfussia, mucilage ducts are formed at an early period, while they seem to be quite absent from the young 
sporophytes of Macroglossum and Angiopteris. In both of these, however, tannin sacs are present in the cotyledon and in the later leaves, as well as in the stem and roots. The solid stele formed by the fusion of the early leaf-traces is retained longer in Macroglossum than in Dancea, and in this respect it also shows unmistakable likeness to Angiopteris.

\section{The Adult Sporophyte.}

The stem of the adult plant is a nearly globular caudex, a foot or more in diameter, completely covered by the closely set leaves. It appears to be strictly radial in structure.

The leaves are more numerous than in Angiopteris, and the habit of the plant more compact. About a dozen leaves are present in the full-grown individual.

The leaves have a relatively short stipe and the numerous pinnae closely set, giving the leaf much the aspect of a large $Z$ amia. The leaflets are almost $50 \mathrm{~cm}$. in length, with a maximum width of about $7 \mathrm{~cm}$. The margin is quite entire, and the apex is sharply acuminate. The closely set veins usually branch close to the midrib, and each branch forks again, each vein in the fertile leaves having above its extremity the very much elongated sorus. The sori are closely set, and form a broad solid band separated from the margin of the leaflet by a narrow border. The sporangia are so crowded as to be scarcely distinguishable, and the appearance of the elongated sorus is very much like the synangium of Danaea, this resemblance being increased by the fact that the sorus is sunk in a sort of trough, and only the upper part of the sporangia appears above the surface of the leaf. Along each side of the sorus is a fringe of fine hairs, the indusium, which is much better developed than it is in Angiopteris. The leaf-base is much enlarged and the stipules extremely conspicuous (P1. XLVIII, Fig. C). The stipules are connected by a large commissure in front.

Pl. XLVIII, Fig. B shows the base of a small plant which, except for its size, is much like the fully grown one. The numerous stout roots are extensively branched, more so than is the case in Angiopteris.

P1. XLVII, Fig. 46 shows a section of the petiole of a leaf from this plant. There were eighteen vascular bundles arranged in a circle inside the margin, and four bundles towards the centre of the section, one of the latter being much larger than the others. Three mucilage ducts $(m$. $)$ were present. Separated from the epidermis by three or four layers of parenchyma cells, there is a broad band of sclerenchyma.

Sections of the base of the stem of this same plant (Pl. XLVII, Fig. 45) showed a structure very much like that of the younger sporophyte. In the centre was a single large bundle, somewhat crescentic in section, and four bundles of smaller size, arranged in pairs, and probably representing double 
leaf-traces. Several mucilage ducts $(m$. $)$ were present in the neighbourhood of the vascular bundles, but none were seen in the cortical region.

THE ROOTS.

The roots (Text-fig. 6) differ from the other Marattiaceae that have been examined in the complete absence of mucilage ducts. There are numerous large tannin sacs, some of which approach the size of mucilage ducts, but the latter seem to be quite lacking. In the outer part of the cortex a few scattered sclerenchyma cells were seen, but there is no distinct ring of sclerenchyma such as occurs in the roots of Danaea. The stele of the root is much like that of other Marattiaceae, but the xylems are less distinct than is usually the case, and extend almost to the centre of the cylinder. The specimen figured had eleven xylems, but there is doubtless some variation in this respect.

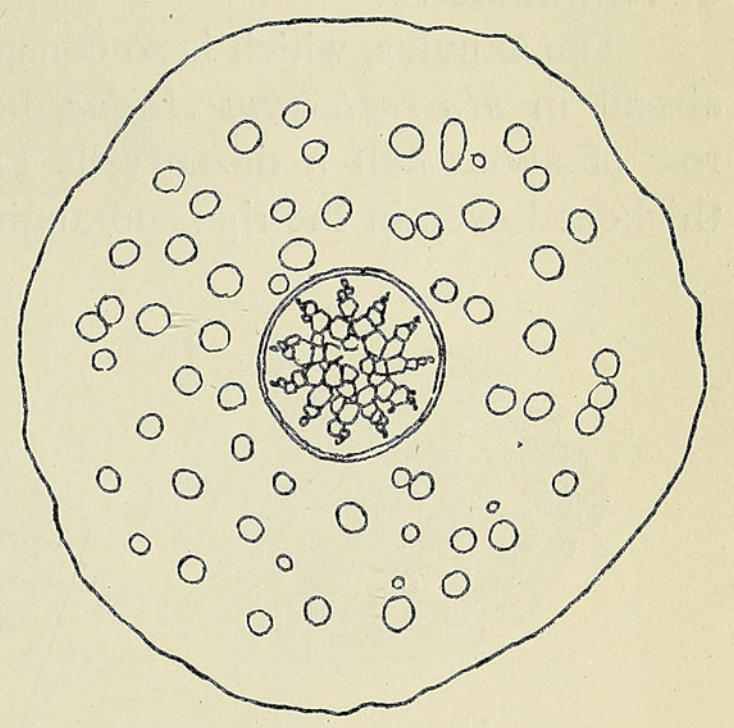

TEXT-FIG. 6. Section of root of an older sporophyte. $\times 16$.

\section{The Sporangia.}

The sorus in Macroglossum is very much longer than in any species of Angiopteris, and much more nearly resembles that of Archangiopteris. It may reach a length of $8 \mathrm{~mm}$., and the number of sporangia in $M$. Alidae about 70 . This is something more than half the maximum number in Archangiopteris. ${ }^{1}$ The appearance of the sorus is very different from that of Angiopteris, as the individual sporangia are less evident, and they are very closely crowded, so that the elongated sorus, as we have seen, closely resembles a true synangium like that of Danaea. In reality, however, the sporangia are quite separate, as in Angiopteris. The resemblance of the sorus to the synangium of Danaea is increased by the development of an elevated ridge between the sori, which are thus partially sunk below the surface of the leaf. The sorus is surrounded by a conspicuous fringe of indusial hairs, which arise from the base of the sporangia and reach to the top. These indusial hairs, which branch repeatedly, are much more evident than in any species of Angiopteris, and are very similar to those found in Archangiopteris.

The sporangia (Text-fig. 7) also are more like those of Archangiopteris than they are like those of Angiopteris. Owing to their position they are

1 Christ, H., and Giesenhagen, K. : Pteridographische Notizen. Flora, lxxxvi, 1899. 
more compressed laterally than in Angiopteris, and are also much less convex on the dorsal surface. In Angiopteris the whole dorsal surface of the sporangium is composed of cells with dense brown contents, probably tannin. These tannin cells in Macroglossum are confined to the upper free portion of the sporangium, and are also much less developed on the inner or ventral face.

The annulus, which is so conspicuous in Angiopteris, is almost entirely absent in Macroglossum Alidae, being represented by a single transverse row of about half a dozen cells (Text-fig. $7, \mathrm{C}$ ), which are hardly at all thickened even in the ripe sporangium.
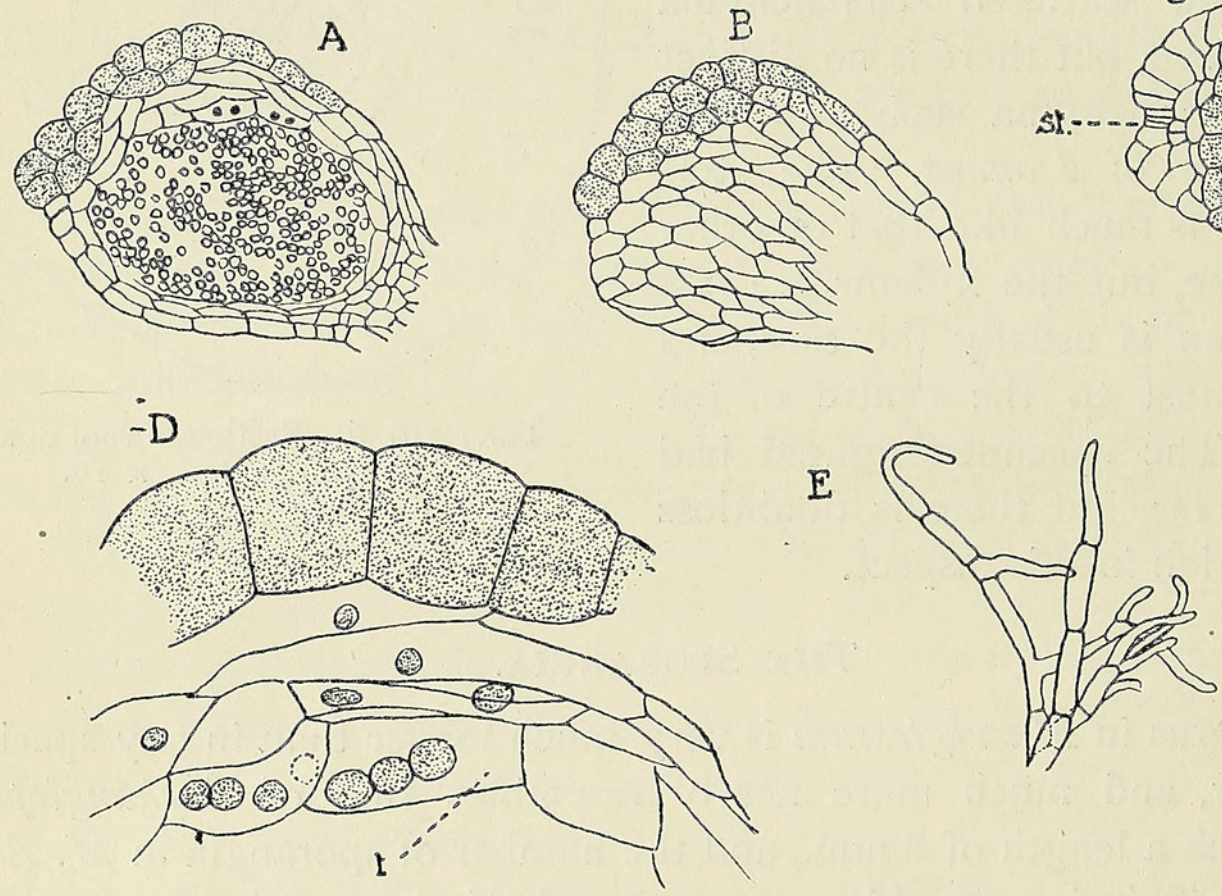

TEXT-FIG. 7. A, Sporangium, median longitudinal section. $\times 75$. B, Surface view of sporangium. C, Apex of sporangium, showing place of dehiscence, st. The shaded cells are tannin (?) cells. D, Wall of sporangium, showing the multinucleate tapetal cells, $t . \quad \times$ about 250 . E, Indusial hair. $\times 75$.

As in other Marattiaceae, the tapetal cells remain intact until a late period and become multinucleate (Text-fig. $7, \mathrm{D}, t$ ). Between the tapetum and the surface of the sporangium there are two or three layers of cells. The dehiscence is by a cleft along the inner face, on either side of which the cells are narrower, but the band of narrow cells bounding the cleft is less conspicuous than in Angiopteris.

Text-fig. 7, E, shows one of the much-branched indusial hairs.

The sorus, as already stated, lies above the end of a vein, and between the sori lies the conspicuous ridge which reaches about half-way up the sporangia, so that their position recalls that of the synangia of Danaea, where, however, the ridge between the synangia is narrow and reaches above the level of the synangium. 
A section of the leaf passing through the sorus (Text-fig. 8) shows the conspicuous bundle belonging to the vein above which the sorus lies; and below the vein is a large mucilage duct. Occupying the centre of the ridge between the sori is a group of sclerenchyma cells, which form a pseudo-vein, which is very evident in horizontal sections. These

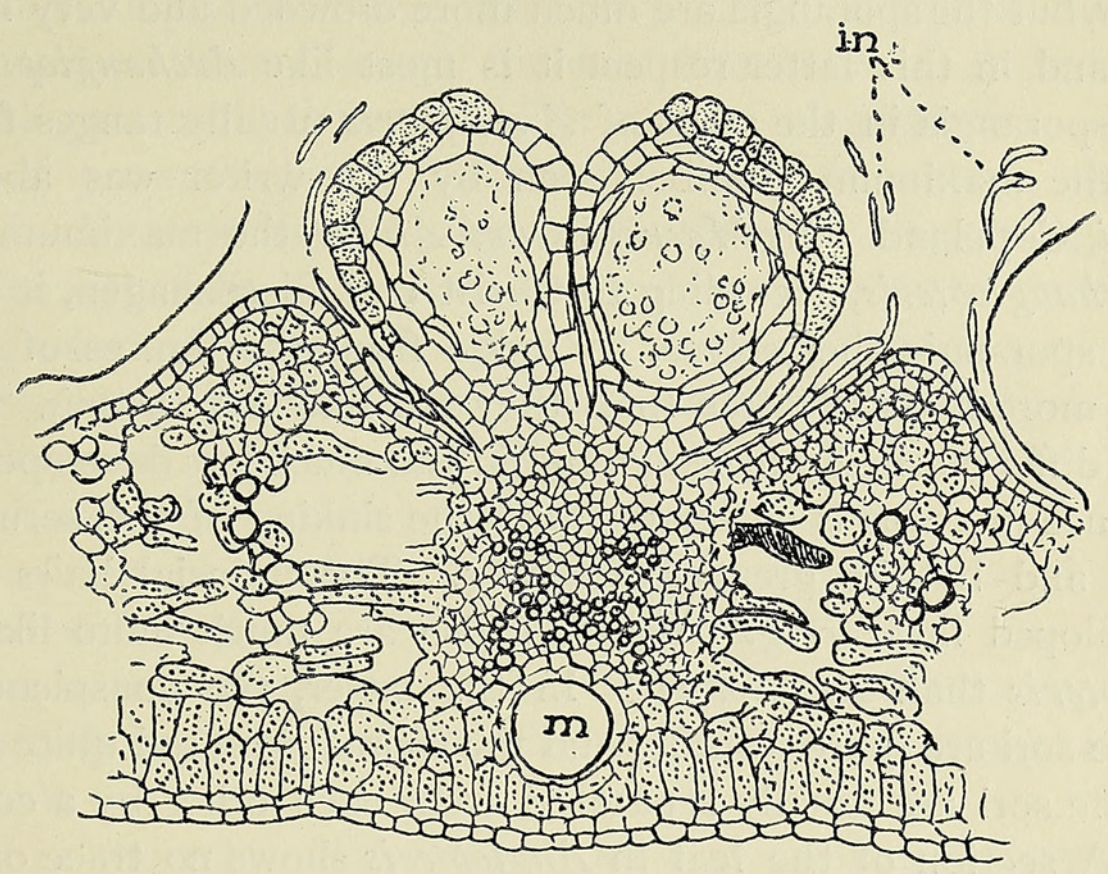

TEXT-FIG. 8. Cross-section of a sporophyll passing through a sorus. $\times$ about $35 . m$., mucilage duct ; in., indusial hairs.

sclerenchyma cells stain strongly with safranin. Very large intercellular spaces are developed in the mesophyll, whose cells are very much elongated. A very conspicuous palisade tissue is present below the ventral surface of the leaf, and this palisade tissue is separated from the epidermis by a single layer of colourless hypodermal cells. Stomata were observed only on the dorsal epidermis.

\section{The Systematic Position of Macroglossum.}

In view of the fact that Raciborski considered the specimen of Macroglossum growing at Buitenzorg to be a species of Angiopteris, it may be well to summarize the points of difference between Macroglossum and Angiopteris.

The gametophytes are very similar, but the antheridia of Macroglossum develop a much greater number of spermatozoids than are found in Angiopteris. The spermatozoids are somewhat smaller and relatively shorter, resembling in the latter respect those of Danaea.

The embryo differs from that of Angiopteris in the very important fact that it develops a large suspensor, thus again suggesting a remote relationship with Danaea. The later development of the embryo, while perhaps most nearly approximating Angiopteris, nevertheless, is in some respects 
intermediate between that of Angiopteris and the other Marattiaceae in having the early leaf-traces remain separate longer than is the case in Angiopteris.

The adult sporophyte is like Danaea and Archangiopteris in the simply pinnate leaves. The sorus is made up of separate sporangia as in Angiopteris, but the sporangia are much more crowded and very much more numerous, and in this latter respect it is most like Archangiopteris. The number of sporangia in the sorus of Angiopteris usually ranges from about 7 to 15 ; the maximum number seen by the writer was about 25 in A. Brooksii, Copeland. In Macroglossum Alidae the maximum exceeded 70; in Archangiopteris, according to Christ and Giesenhagen, it may reach I20. The sporangia themselves, to judge from the figures of Archangiopteris, are more like the latter than they are like Angiopteris. From the latter they differ markedly in shape, and in the much less developed annulus. The difference in shape is correlated with the sinking of the sorus between the ridges and by the greater crowding. The indusial hairs are much better developed in Macroglossum, and also are much more like those of Archangiopteris than Angiopteris. In the latter, the conspicuous ridges between the sori are quite wanting and the sporangia stand quite free above the leaf; the sori are usually separated from each other by a considerable interval. A section of the leaf in Angiopteris shows no trace of the large mucilage ducts found in Macroglossum, and the palisade tissue is not so well marked, although it is well developed in some species.

While it is evident that Macroglossum should be included in the Angiopterideae, its affinities seem to be with Archangiopteris rather than with Angiopteris. The resemblances to Danaea are interesting, but it is doubtful whether they indicate anything more than analogies. It is of course possible that the elongate sorus with its individual sporangia may have been derived from the solid synangium of such a form as Danaea, but there is no positive evidence that such has been the case.

Of the two species examined, $M$. Smithii, the plant growing at Buitenzorg, is more like Angiopteris than is $M$. Alidae. The sori are less elongated, and the small ones are not very unlike those of Angiopteris. Moreover, the sporangia themselves have the annulus somewhat better developed than is the case in $M$. Alidae. However, the differences between this species and $M$. Alidae are not very marked, and it is evident that the two are closely related, although probably specifically distinct.

\section{SUMMARY.}

1. The genus Macroglossum comprises two known species, M. Alidae, Copeland, first collected at Bau in Sarawak, Borneo, and afterwards at Mount Penrissen, Sarawak; M. Smithii (Angiopteris Smithii, Raciborski), 
growing in the Botanical Gardens at Buitenzorg, Java, but of unknown origin.

2. The full-grown plant approaches in size the larger species of Angiopteris; the leaves may reach a length of 4 metres. The plant differs much in appearance from Angiopteris, the leaves being more numerous and upright, and simply pinnate. The very much elongated and partially immersed sori are also strikingly different from those of Angiopteris.

3. The gametophyte is much like that of Angiopteris. It may reach a length of 3 centimetres. Branching is not uncommon, either by adventitious buds, or occasionally by a dichotomy of the growing point.

4. The antheridia occur both on the dorsal and ventral surfaces. They are of the usual type, but the number of sperm-cells is probably greater than in any other Marattiaceae. The spermatozoids are relatively small and less elongated than those of Angiopteris.

5. The archegonia are much like those of Angiopteris.

6. The embryo develops a conspicuous suspensor and thus resembles the embryo of Danaea.

7. The later development of the embryo seems to correspond to that of the other Marattiaceae. The apical cell of the stem is not always clearly demonstrable.

8. As in the other Marattiaceae, no true cauline stele is developed in the young sporophyte, and the vascular system of the axis is composed entirely of leaf-traces.

9. The structure of the axis in the young sporophyte is to a certain extent intermediate between that of Danaea and Angiopteris.

10. The cotyledon is much like that of Angiopteris; the first leaves, about ten, remain simple. Stipules first appear in the third leaf. The first leaf-trace shows a collateral structure.

II. The primary root is usually diarch. A single root is formed for each of the early leaves. The primary root has a single initial cell.

12. The leaf of the adult sporophyte differs from that of Angiopteris in its simply pinnate form, as well as in the anatomy of the leaflets. The latter show a conspicuous mucilage duct below the sorus, and a better developed palisade tissue.

I3. The sporangia of Macroglossum, especially $M$. Alidae, are smaller than those of Angiopteris, and very much more numerous. The sorus is much more compact, and partially sunk in a trough formed by elevated ridges between the sori, while in Angiopteris no such ridges are present. The annulus is very slightly developed in Macroglossum, and the indusial hairs very much more conspicuous than in Angiopteris.

14. The roots of the adult plant have no mucilage ducts, thus differing from the other Marattiaceae that have been described.

I5. Macroglossum should undoubtedly be placed in the Angiopteridiae, 
but its affinities are with Archangiopteris rather than with Angiopteris. Of the two species examined, $M$. Smithii is nearer to Angiopteris than is M. Alidae.

\section{EXPLANATION OF PLATES XLVI-XLVIII.}

Illustrating Professor Douglas H. Campbell's paper on the Structure and Affinities of Macroglossum Alidae, Copeland.

\section{PLATE XLVI.}

Fig. I. Young gametophyte seen from below, showing the first antheridia. $\times 2$.

Fig. 2. The apical region of the same. $\times 20$. Young archegonia.

Figs. 3, 4. Older gametophytes. $\times$ 2. Fig. 4 seen from below, showing the thick midrib covered with old archegonia.

Fig. 5. An old gametophyte, showing the formation of adventitious buds, $b . \quad \times 2$.

Fig. 6. Gametophyte, with very young sporophyte attached. $\times 2$.

Fig. 7. A large gametophyte which has branched dichotomously; each branch has a sporophyte. $\times 2$.

Fig. 8. Sporophyte with three fully developed leaves, still attached to the gametophyte, pr. $\times 2$.

Fig. 9. Base of the third leaf, showing the stipules, st. $\times 4$.

Fig. 10. Young fifth leaf. $\times 2$.

Fig. II. Base of a young sporophyte, with eight fully developed leaves; st., stipules. $\times 2$.

Fig. I 2. Surface view of the apical region of the gametophyte. $\times 3^{6} 5$.

Fig. I3. Longitudinal section passing through the apical region of the gametophyte. $x$, one of the marginal initial cells; , young archegonium. $\times 3^{6} 5$.

Fig. I4. Cross-section of the gametophyte, showing the position of the mycorrhiza, $m$. $\times 90$.

Figs. I5-I9. Stages in the development of the antheridium, seen in longitudinal section; Figs. $15^{-17}, \times 600 ;$ Figs. $18,19, \times 365$. m., mantle cells.

Fig. 20. Surface view of a young antheridium.

Fig. 2I. Surface view of an older antheridium, showing the triangular opercular cell.

Figs. 22, 23. Spermatocytes, showing the development of the spermatozoid. bl., blepharoplast. $\times$ about 900 .

Fig. 24. Spermatozoid of Angiopteris. $\quad \times$ about 900.

\section{PLATE XLVII.}

Figs. 25-3I. Development of the archegonium, seen in longitudinal section. $\quad \times 600$. 0 , eggcell; v.c., ventral canal cell.

Fig. 32. Full-grown archegonium, showing two distinct neck canal cells. $\times 365$.

Fig. 33. Two archegonia of Angiopteris. $\quad \times 36_{5}$.

Fig. 34. Archegonium containing a one-celled embryo. $\times 600$.

Fig. 35. One.celled embryo, elongated laterally.

Fig. 36. Two-celled embryo ; the upper (hypobasal) cell becomes the suspensor.

Fig. 37. Median section of an older embryo, showing the very large suspensor, sus. $\times$ about 90 .

Fig. 38. The same embryo more highly magnified; the large shaded cell is perhaps the initial cell for the stem-apex.

Fig. 39. A young embryo which was arrested in its development.

Figs. 40-42. Three horizontal sections of an embryo somewhat older than that shown in Fig. 38 . The initial of the root, $r_{.}$, is shown in the middle section. st., stem-initial (?); sus., base of the suspensor. 
Fig. 43. Longitudinal section of a sporophyte which has broken through the gametophyte. $\times 35$. The vascular strand of the cotyledon and primary root are continuous : the second leaf $\left(L^{2}\right)$ was just visible, and also the beginning of the second root (not visible in this section).

Fig. 44. The apical region of the same. $\times 365$. st., stem-initial (?); $L^{3}$, initial for third leaf (?); $t r$., tracheide from the central region of the common primary vascular bundle.

Fig. 45. Cross-section of the axis of an older sphorophyte. $\times 2$. Five vascular bundles and as many mucilage ducts are visible. $r$, $r$, roots.

Fig. 46. Cross-section of the petiole of a leaf from the same plant. $\times 2$.

Fig. 47. Margin of the leaf of a mature sporophyte, showing the much elongated sori. $\times 3$.

\section{PLATE XLVIII.}

Fig. A. Young sporophyte of Macroglossum Alidae. $\times \frac{2}{3}$.

Fig. B. Caudex of a young sporophyte, showing the leaf-bases and the much-branched roots.

Fig. C. Leaf-base from a somewhat older specimen. 
Annals of Botany
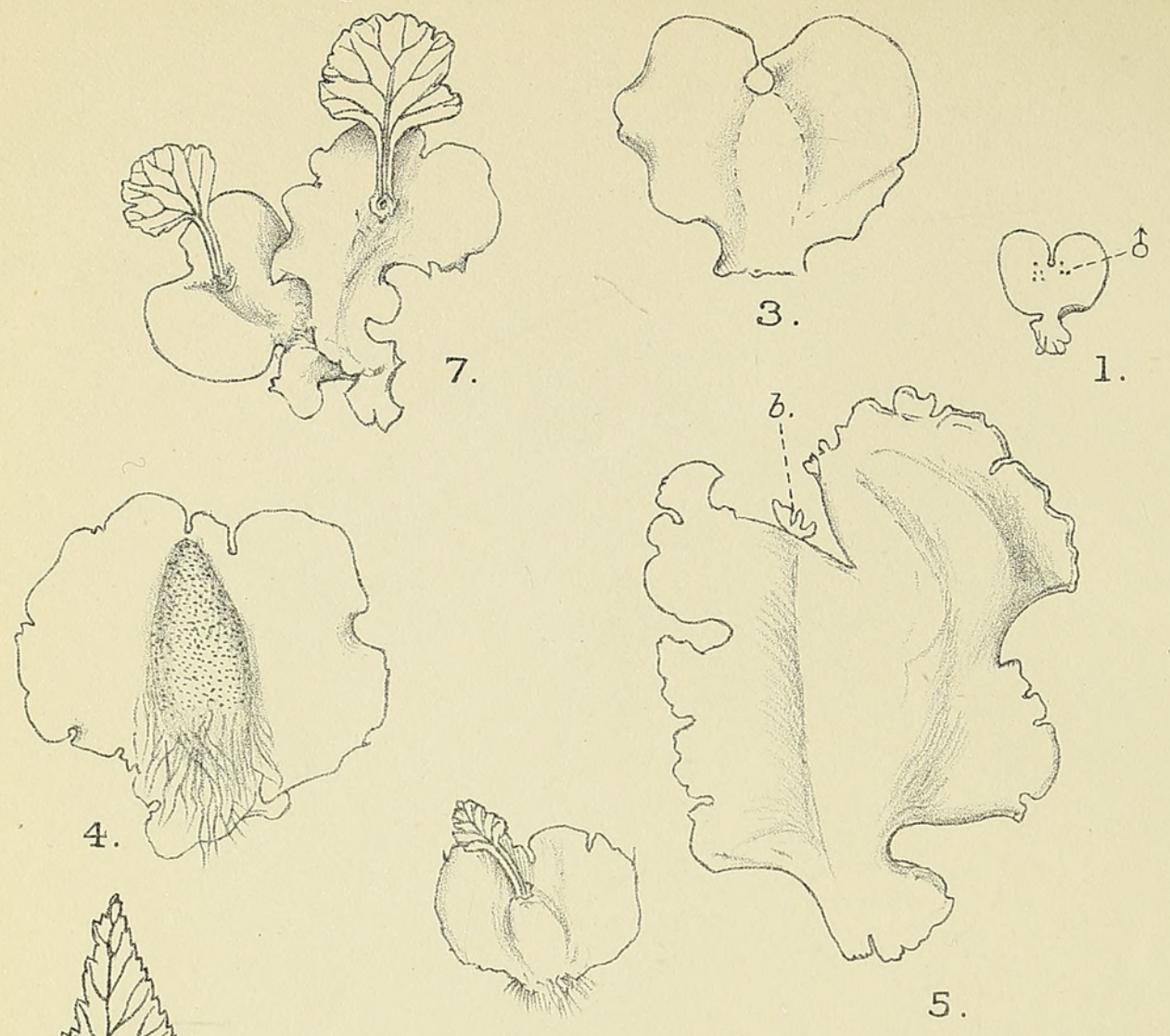

6.
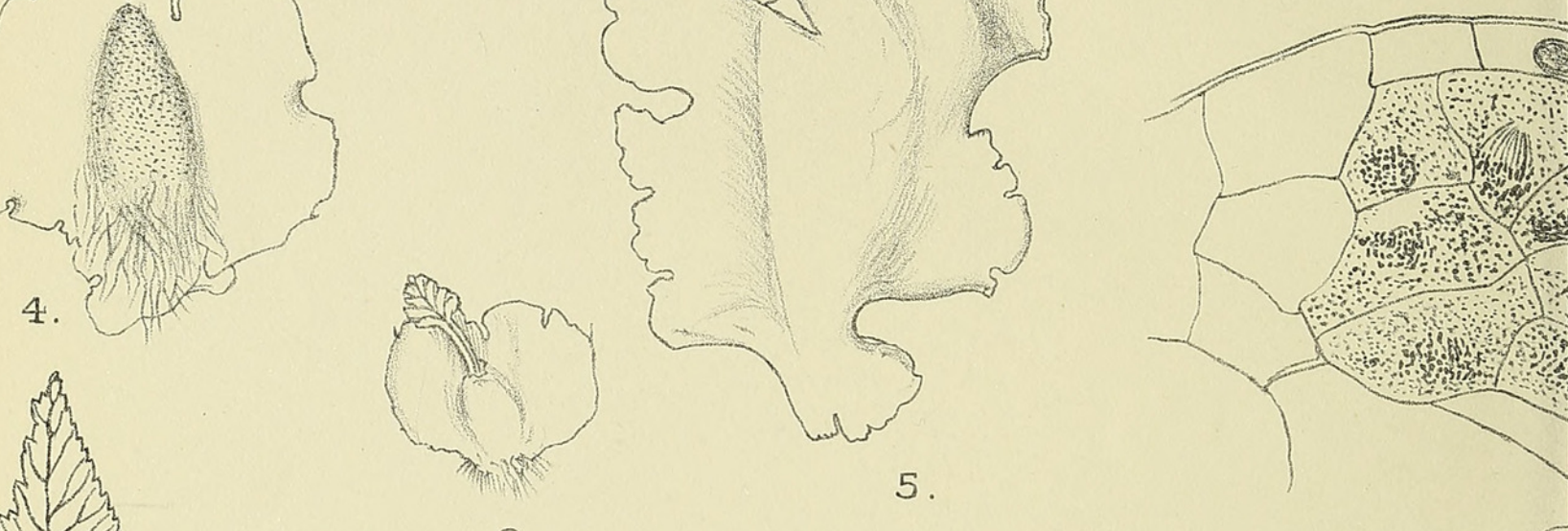

5.

16.

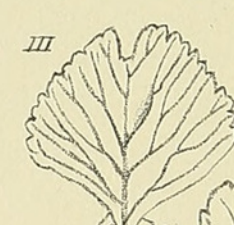

$\sqrt{ }$

10.
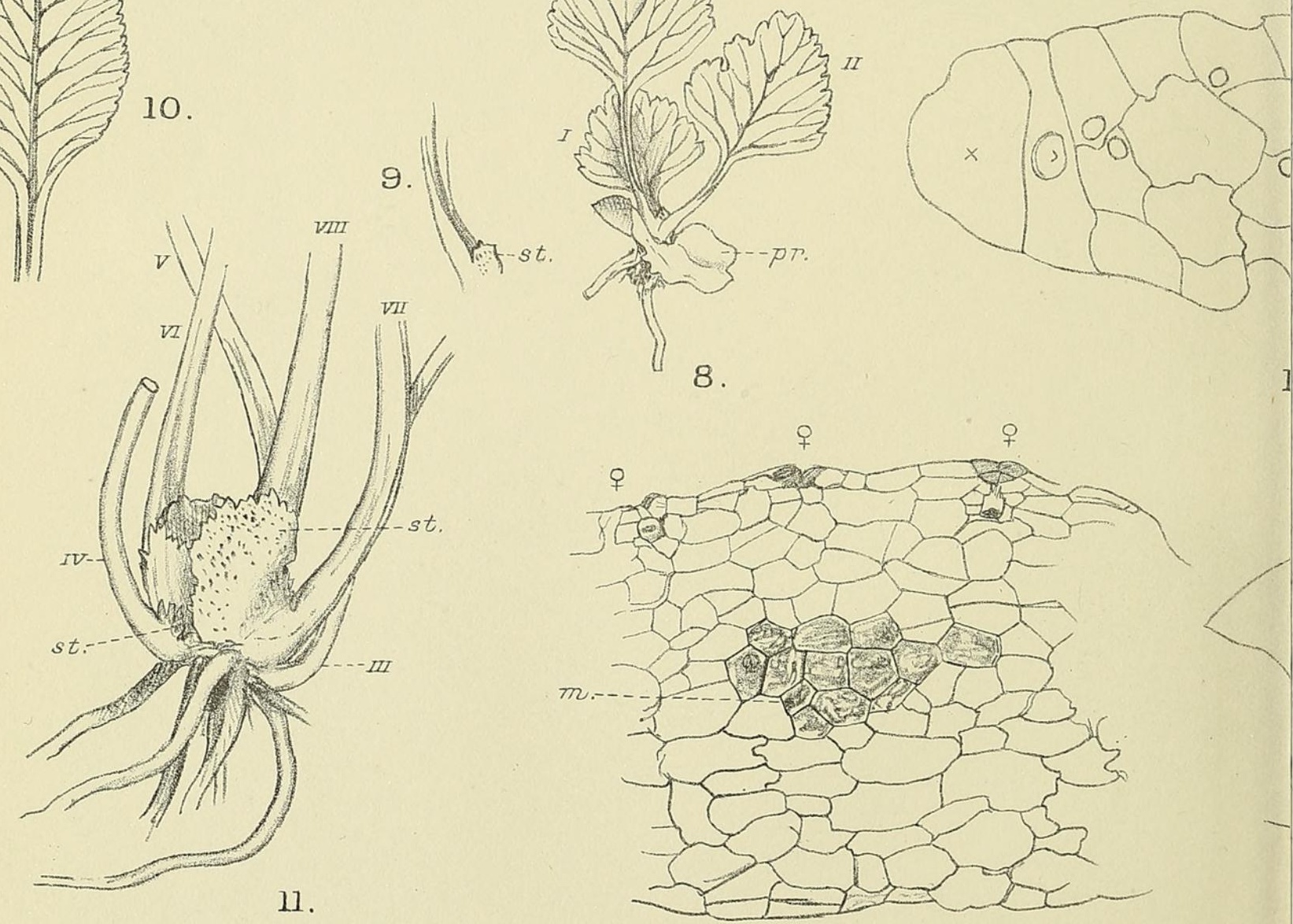

14.

D.H.Campbell del.

CAMPBELL. MACROGLOSSUM. 
Vol. XXVIII,PL. XLVI.
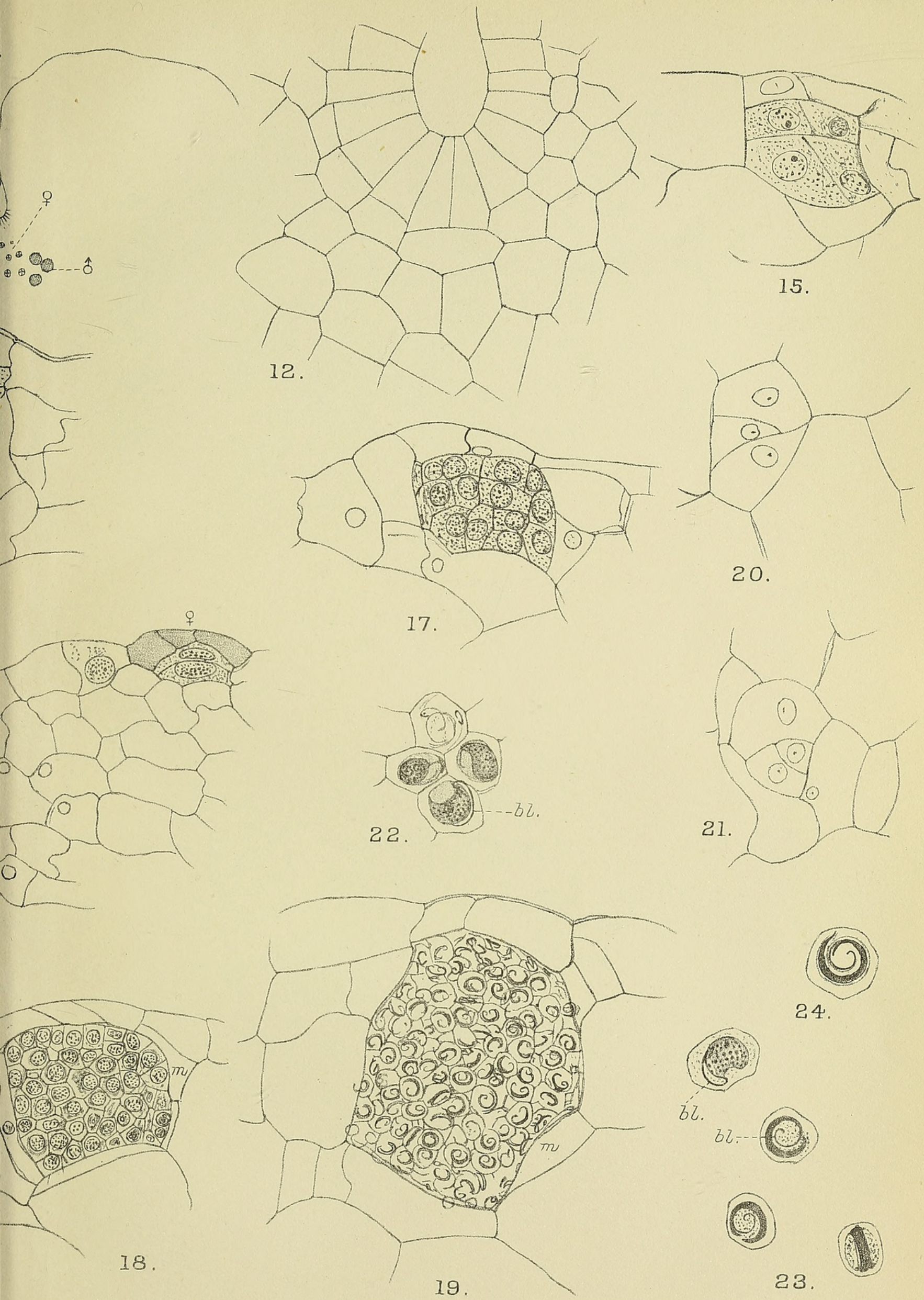

20.

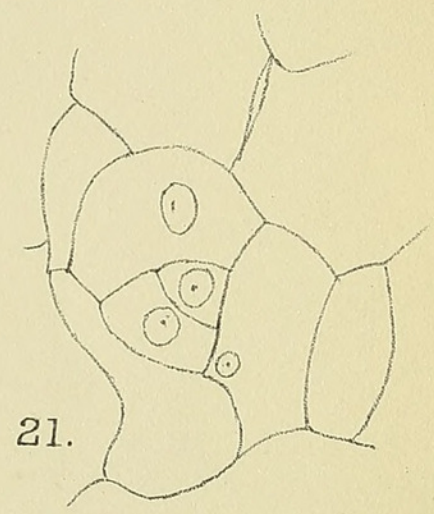

15. 


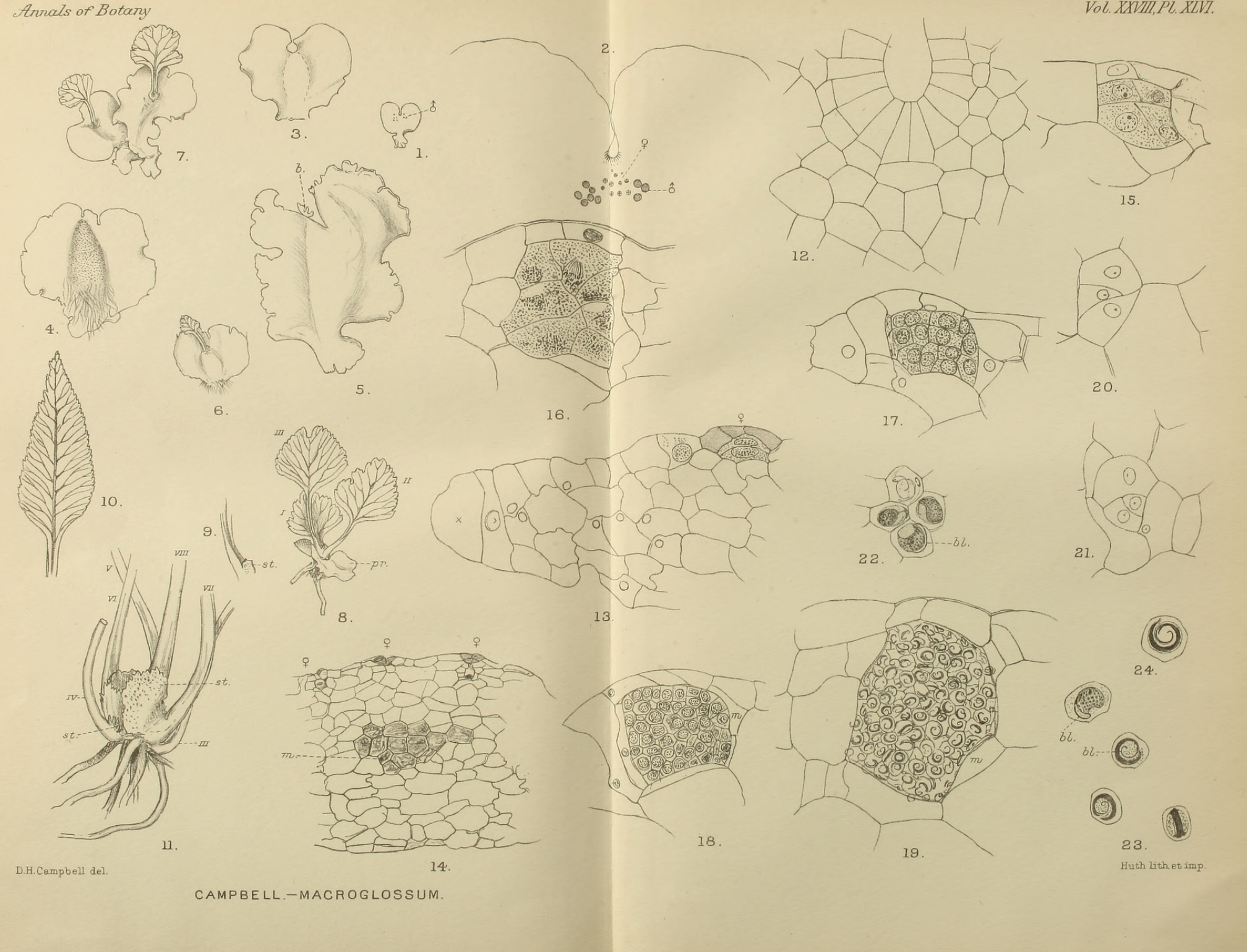




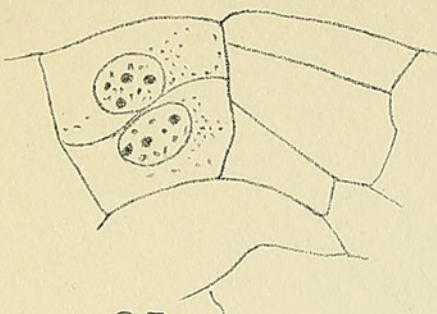

25.

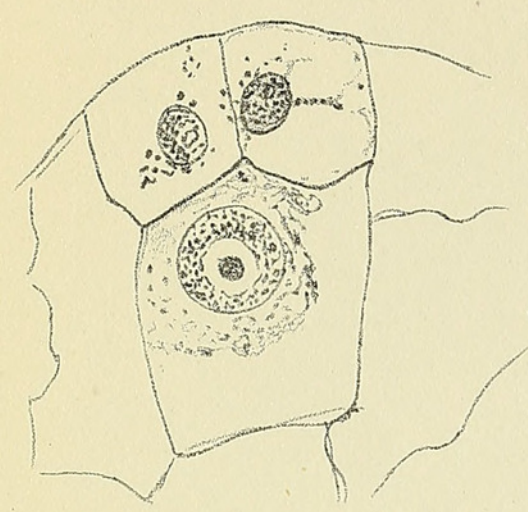

28.
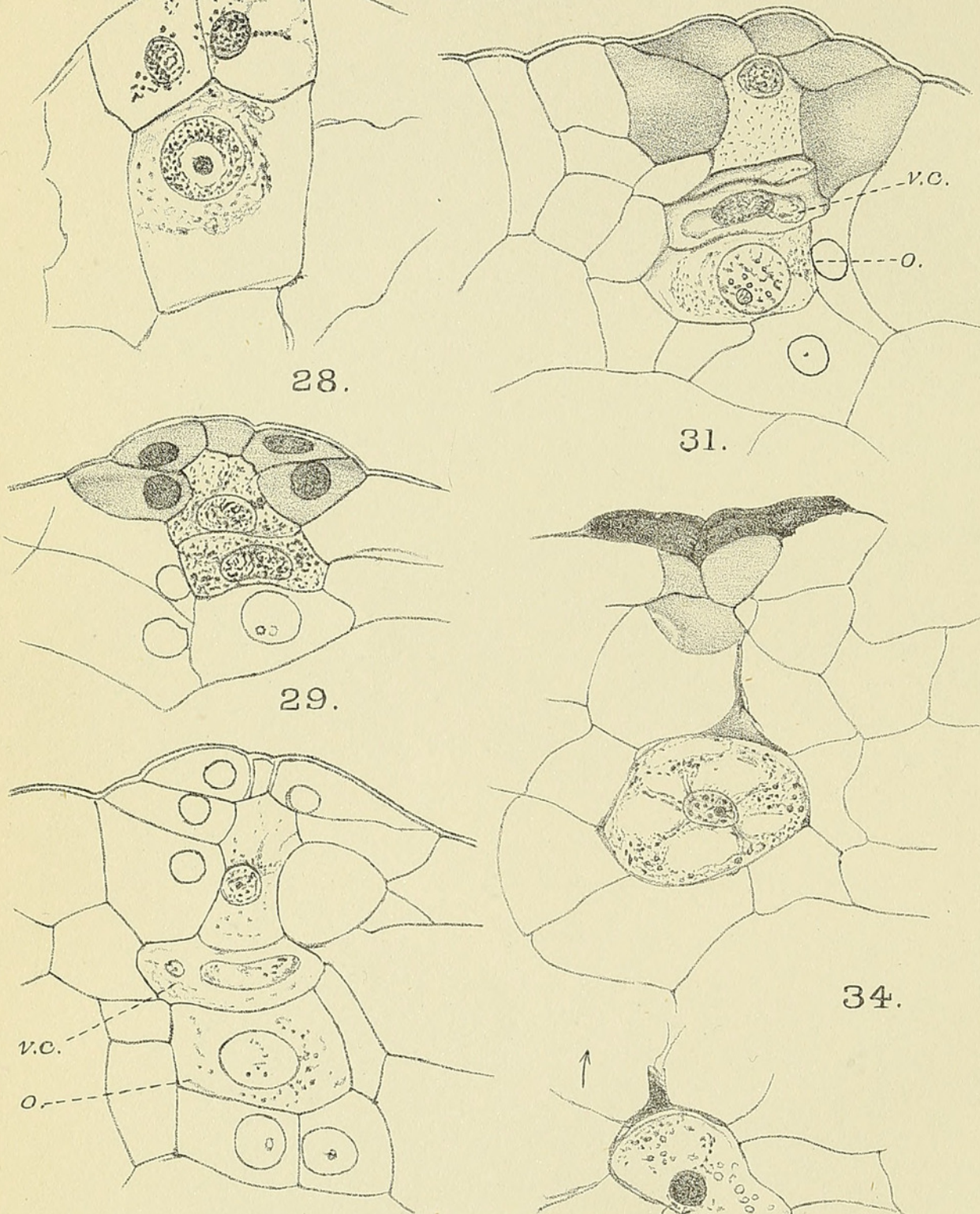

31.
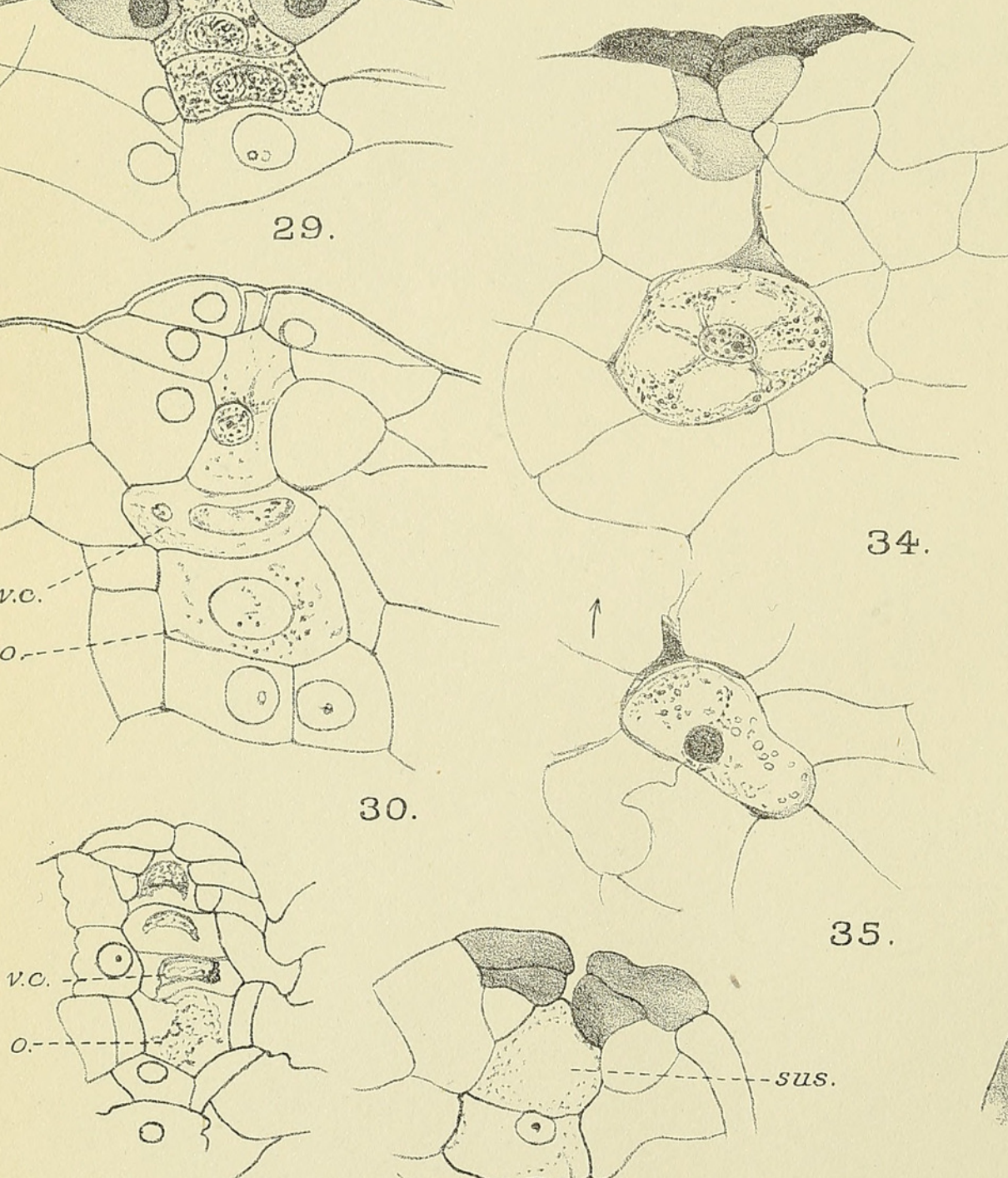

32.

30.

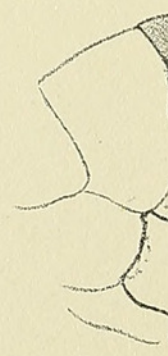

35

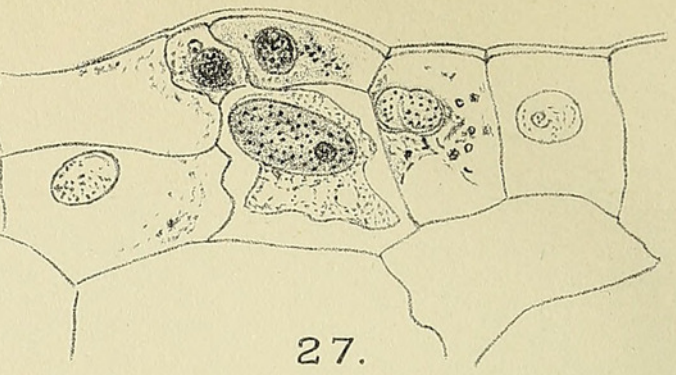

27.

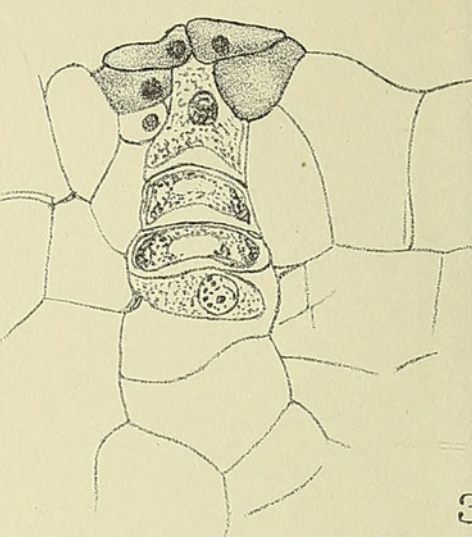

47.
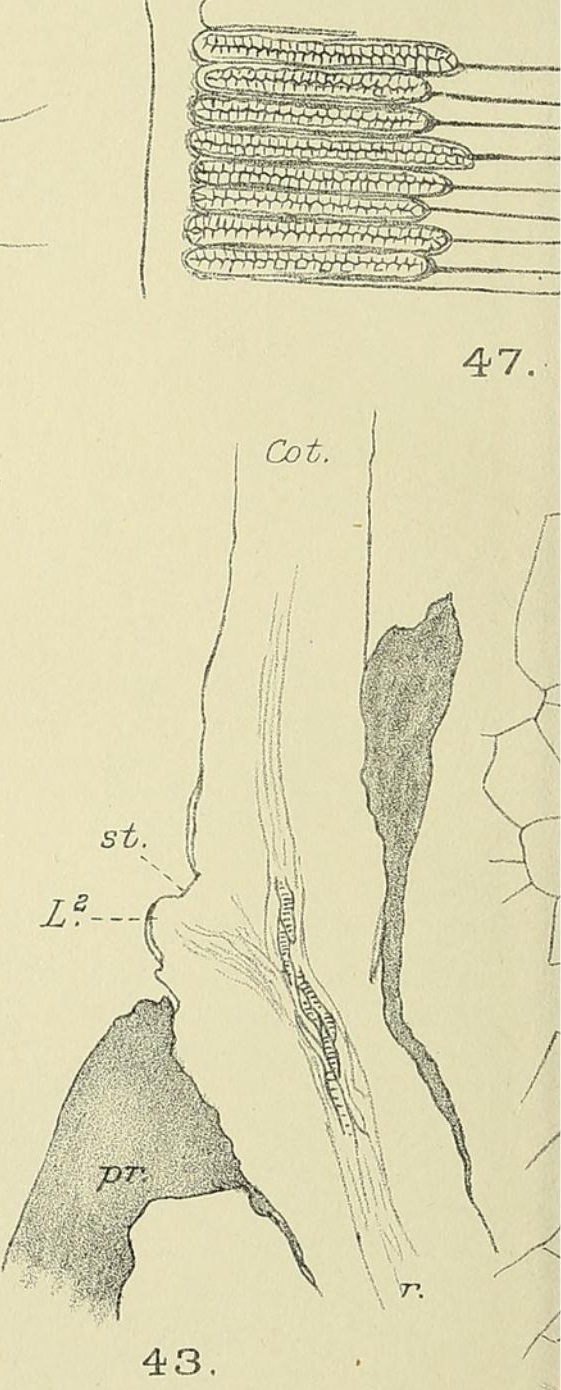

D.H.Campbell del. 
(6:-0)
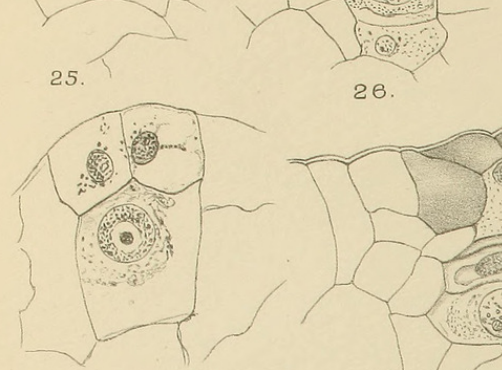

28.
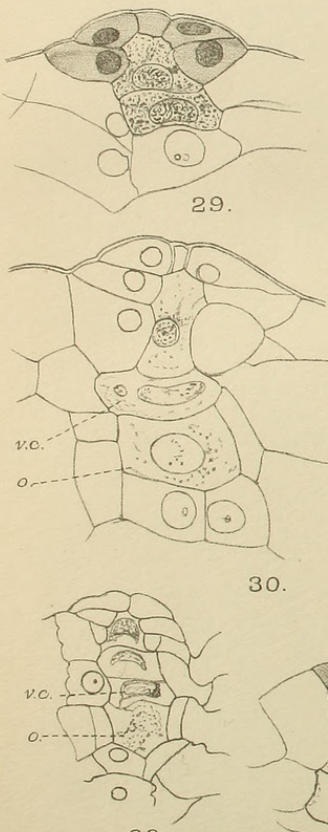

32.

D. H.Campbell del.

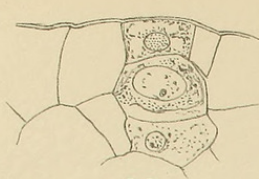

26.

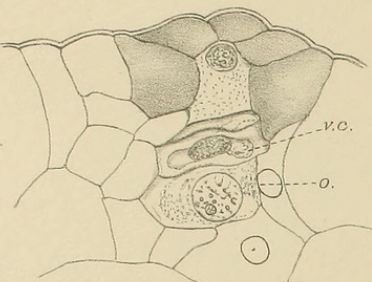

31.
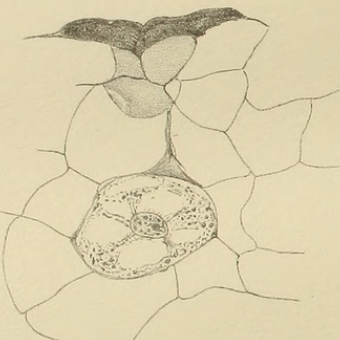

34

30

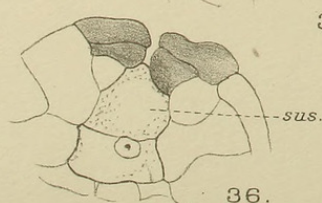

35.

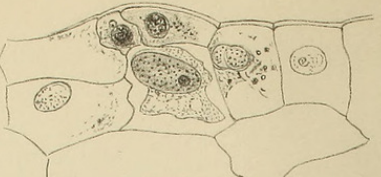

27.

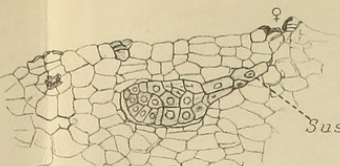
तरी पिरे 37 .

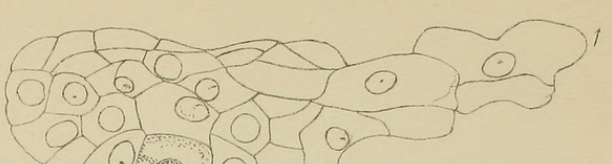

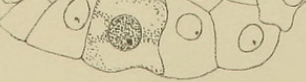

38

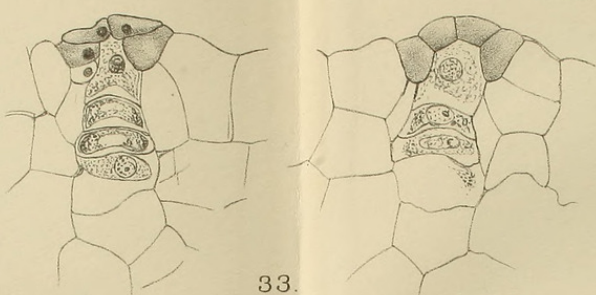

33.

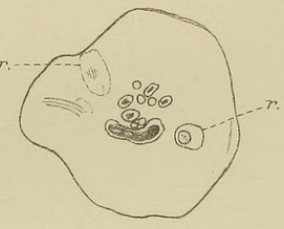

45.

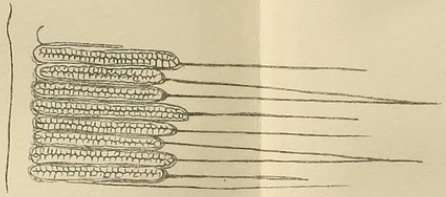

47.

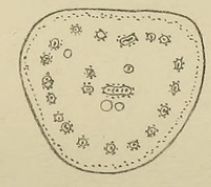

46.

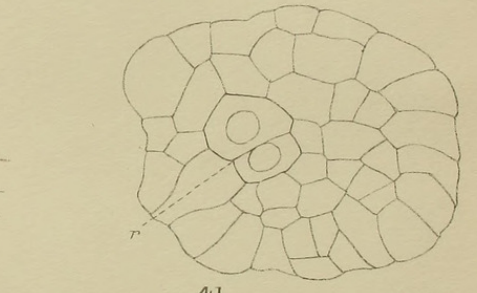

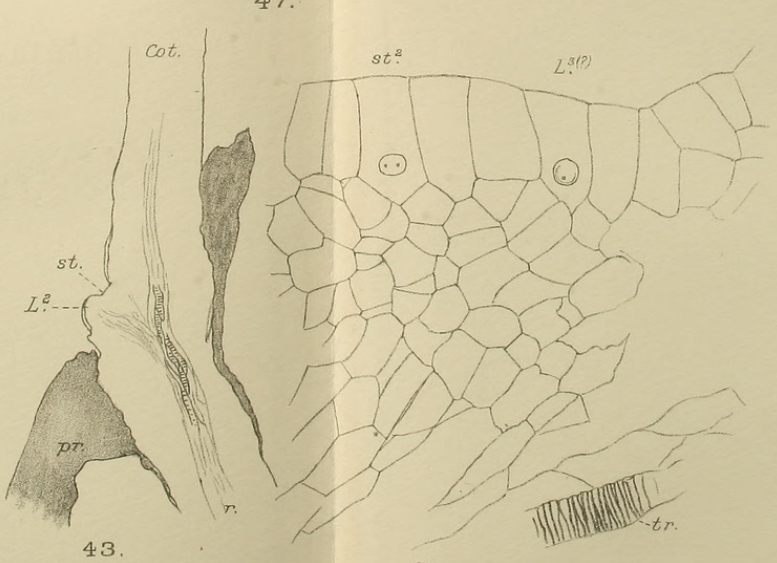

44.

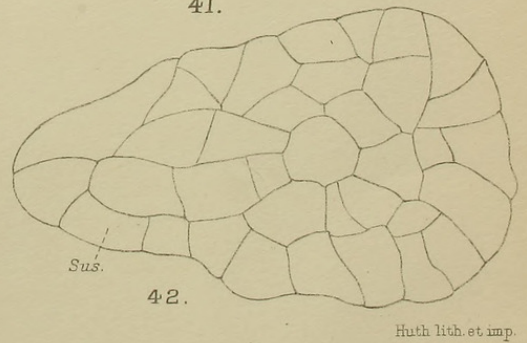


Annals of Botany

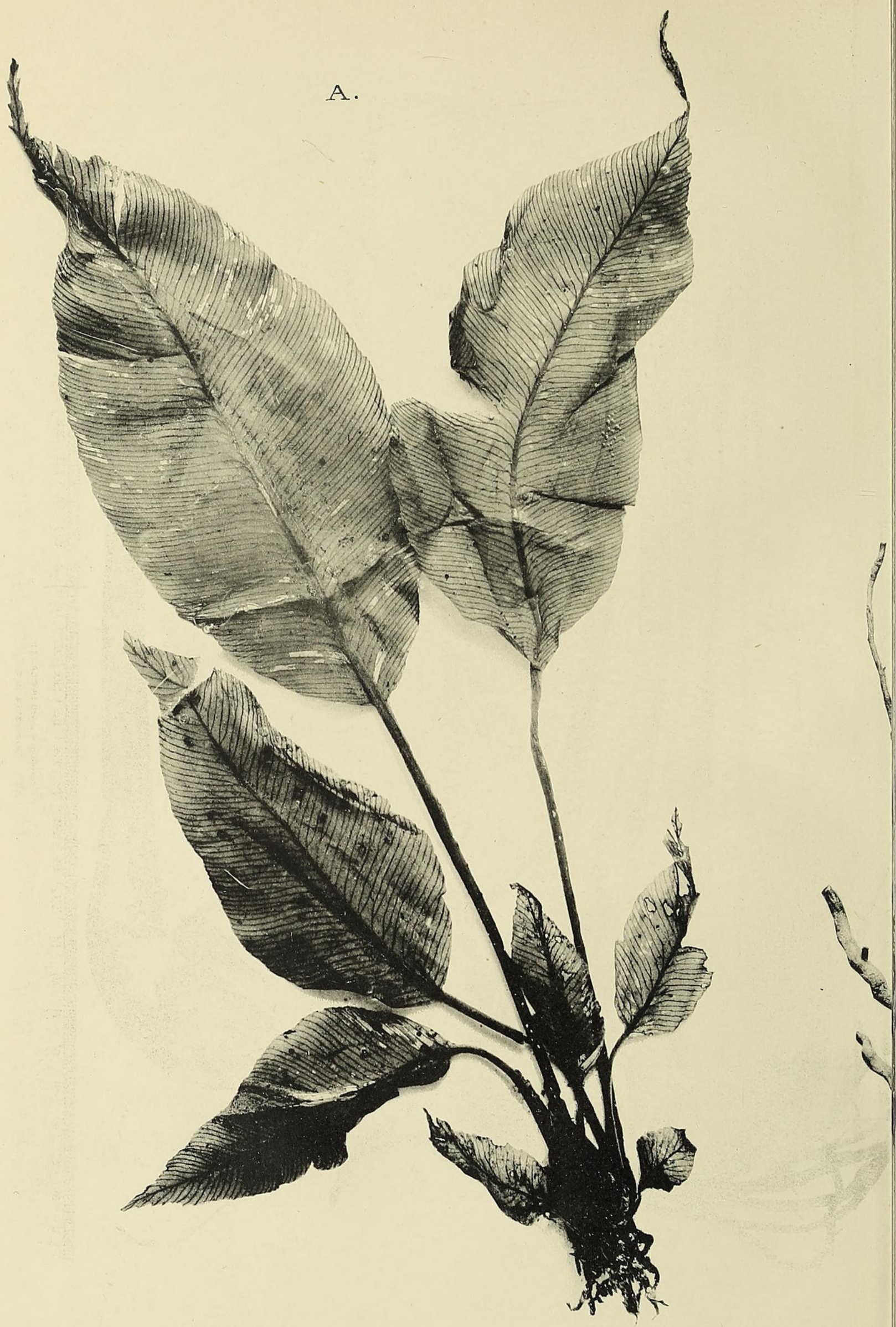

CAMPBELL - MACROGLOSSUM. 
Vol.XXVIII,PL,XLVIII.

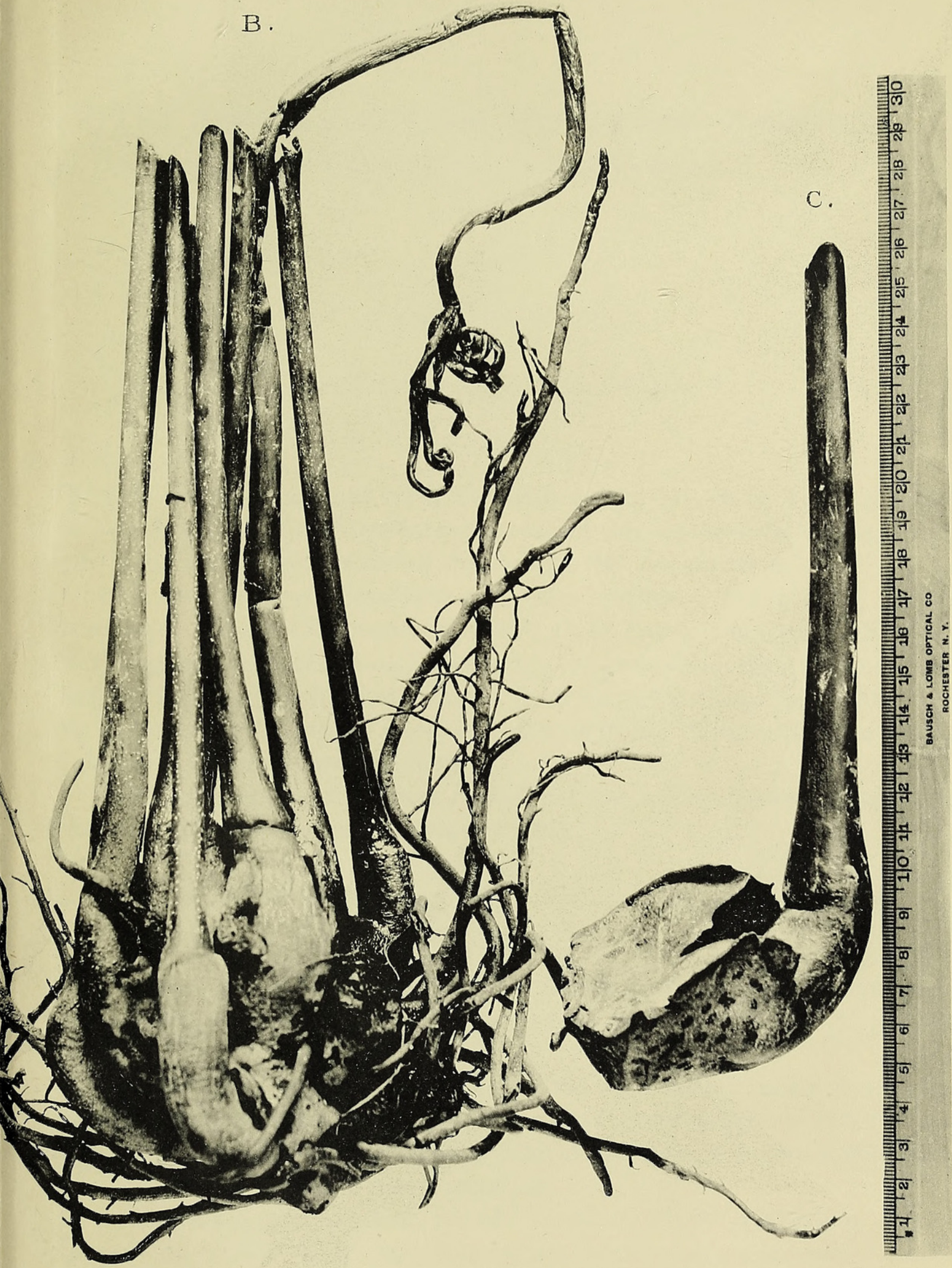



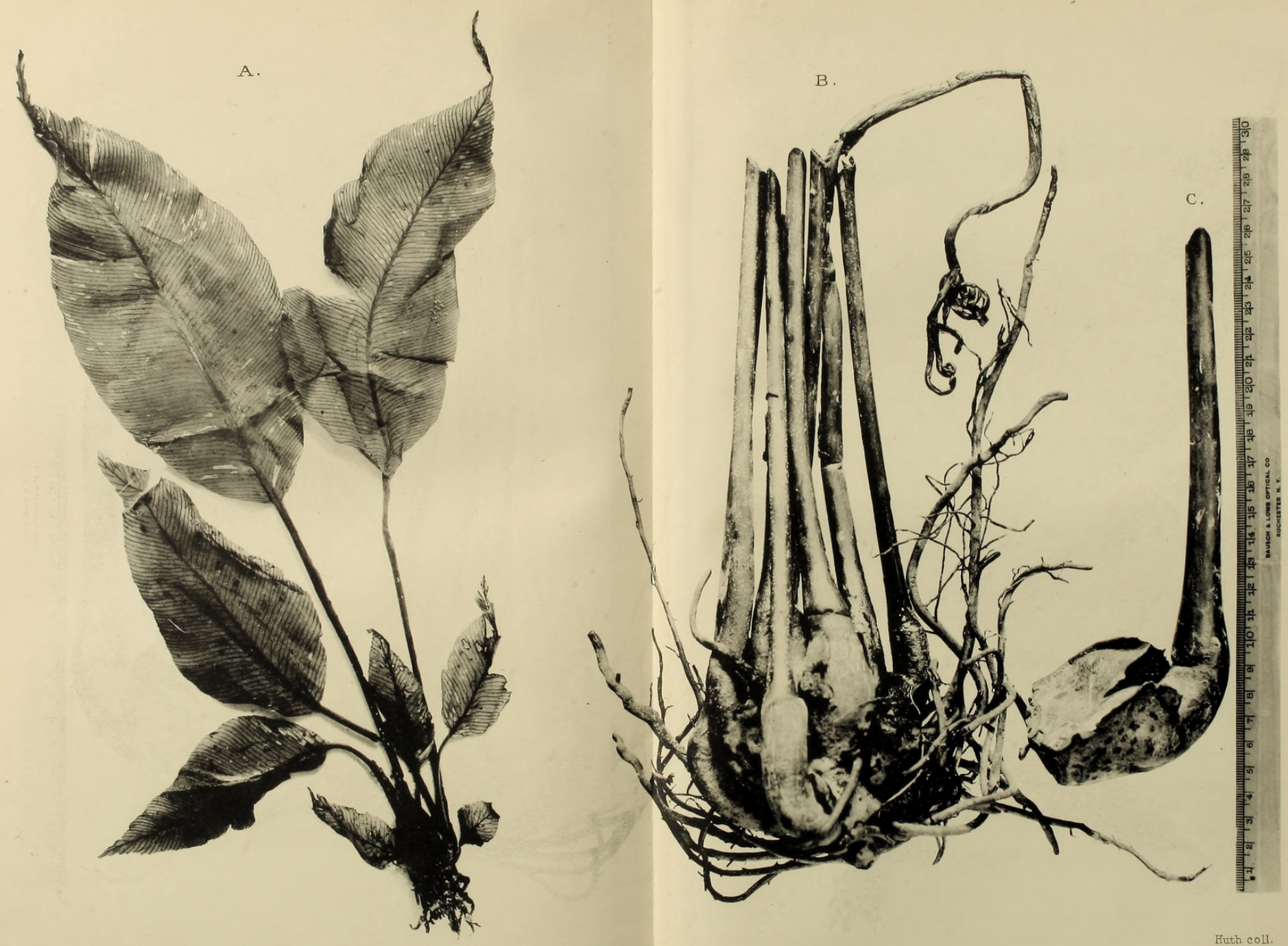


\section{$2 \mathrm{BHL}$ Biodiversity Heritage Library}

Campbell, Douglas Houghton. 1914. "The structure and affinities of Macroglossum alidae, Copeland." Annals of botany 28, 651-669.

https://doi.org/10.1093/oxfordjournals.aob.a089527.

View This Item Online: https://www.biodiversitylibrary.org/item/236856

DOI: https://doi.org/10.1093/oxfordjournals.aob.a089527

Permalink: https://www.biodiversitylibrary.org/partpdf/320044

\section{Holding Institution}

Smithsonian Libraries

\section{Sponsored by}

Biodiversity Heritage Library

\section{Copyright \& Reuse}

Copyright Status: Not in copyright. The BHL knows of no copyright restrictions on this item.

This document was created from content at the Biodiversity Heritage Library, the world's largest open access digital library for biodiversity literature and archives. Visit BHL at https://www.biodiversitylibrary.org. 